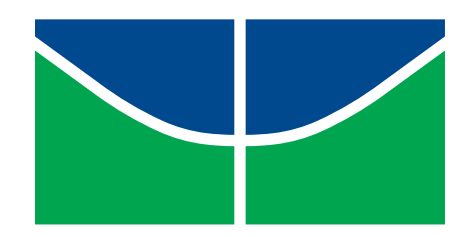

\author{
Universidade de Brasília \\ Instituto de Ciências Exatas
}

Departamento de Matemática

\title{
HISTÓRIA DA MATEMÁTICA PARA A PRÁTICA DOS PROFESSORES DO ENSINO MÉDIO
}

ANA GABRIELA DE BRITO DE MOURA

Brasília

2016 
Ficha catalográfica elaborada automaticamente, com os dados fornecidos pelo(a) autor(a)

de Brito de Moura, Ana Gabriela

História da Matemática para a prática dos professores do Ensino Médio / Ana Gabriela de Brito de Moura; orientador Josinalva Estácio Menezes. -Brasilia, 2016. $83 \mathrm{p}$.

Dissertação (Mestrado - Mestrado Profissional em Matemática) -- Universidade de Brasília, 2016.

1. História da Matemática. 2. Recurso didático. 3. Prática. 4. Ensino Médio. 5. Ensino da Matemática. I. Estácio Menezes, Josinalva, orient. II. Título. 
Universidade de Brasília

Instituto de Ciências Exatas

Departamento de Matemática

\title{
HISTÓRIA DA MATEMÁTICA PARA A PRÁTICA DOS PROFESSORES DO ENSINO MÉDIO
}

\author{
ANA GABRIELA DE BRITO DE MOURA
}

Dissertação apresentada como parte dos requisitos para a obtenção do título de Mestre junto ao Programa de Pós-Graduação em Matemática Profissional em Rede Nacional - PROFMAT, do Departamento de matemática da Universidade de Brasília.

Orientadora: Prof. Dra. Josinalva Estacio Menezes

Brasília

2016 


\title{
História da Matemática para a prática dos professores do Ensino Médio
}

\author{
Por
}

\section{Ana Gabriela de Brito de Moura*}

Dissertação apresentada ao Departamento de Matemática da Universidade de Brasília, como parte dos requisitos do "Programa" de Mestrado Profissional em Matemática em Rede Nacional - PROFMAT, para obtenção do grau de:

\section{MESTRE}

Brasília, 19 de agosto de 2016.

Comissão Examinadora:
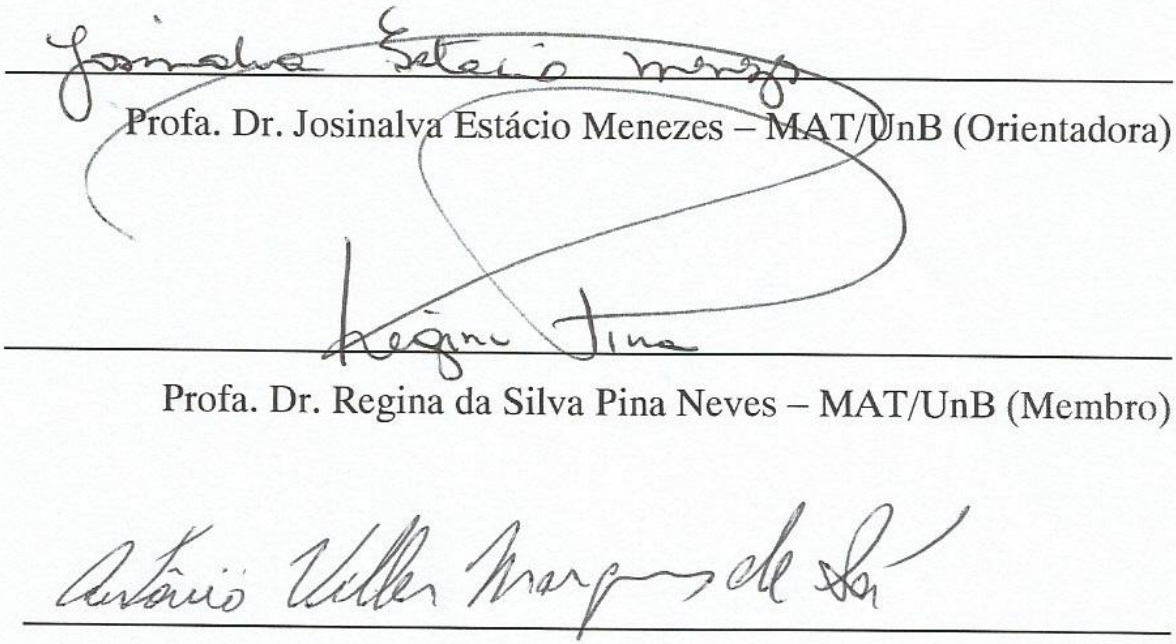

Prof. Dr. Antônio Villar Marques de Sá- UnB (Membro) 


\section{Dedicatória}

Dedico meu título de mestre ao Rômulo: marido e melhor amigo. 


\section{Agradecimentos}

A Deus, pelas bênçãos concedidas.

À professora Doutora Josinalva Estacio Menezes, pelas orientações, pelos incentivos morais, pelo carinho e por dividir sua sabedoria comigo. Serei eternamente grata por seu apoio.

Ao meu marido e melhor amigo: Rômulo, por ser meu companheiro em todos os momentos.

Aos meus pais, Gilberto e Josinete, e minhas lindas irmãs, Marina e Ludmila, pela paciência e por acreditarem na realização dos meus sonhos.

Aos meus amigos, que com muita compreensão entenderam minha ausência em prol dos estudos.

Aos meus colegas da turma do mestrado, pela união, pela ajuda mútua, pelo compartilhamento de experiências e pelas risadas.

Aos professores do PROFMAT, em especial professor Doutor Rui Seimetz, por acreditar em uma educação de qualidade.

À CAPES pelo apoio financeiro a este trabalho. 
"Cada tradição tem a sua explicação. Todas elas revelam a grande ansiedade que o homem tem de conhecer as origens."

Ubiratan D'Ambrosio (1997, p. 15) 


\section{Resumo}

Esta dissertação corresponde a uma pesquisa na qual se investigou o potencial da história da matemática como recurso didático adicional para o Ensino Médio e se propõe um conjunto de textos referentes aos conteúdos principais ministrados neste nível de ensino. Os referidos textos podem ter um potencial motivador para a aprendizagem de matemática, visto que têm como objetivo o auxílio na prática dos professores em sala de aula. Para realizar a pesquisa, buscaram-se as ideias básicas dos principais autores sobre o uso a história no ensino da matemática, as principais pesquisas sobre o tema, como também a inserção da história em forma de textos em livros didáticos, paradidáticos e universitários sobre história da matemática. Para alguns conteúdos científicos de matemática do Ensino Médio, propostos pelo Currículo em Movimento, foi feito um apanhado histórico sobre o assunto, destacando: principais mentores, contexto em que foi concebido, aplicações e curiosidades, quando for julgado relevante para o entendimento do tema. Além disso, foi feita uma pesquisa empírica junto a professores do Distrito Federal, na qual se coletaram opiniões dos mesmos sobre o uso da história no Ensino Médio. Acredita-se no potencial dos textos como recurso didático no sentido de fornecer contexto e significado à aprendizagem dos estudantes, motivar o interesse dos alunos pela matemática, obter resultados mais significativos no processo de ensino-aprendizagem dos conteúdos de matemática.

Palavras-chave: História da matemática. Recurso didático. Prática. Ensino Médio. Ensino de matemática. 


\begin{abstract}
This work is a survey in which we investigated the potential of the history of mathematics as an additional educational resource for high school and proposes a set of texts referring to the main content taught in this level of education. These texts may have a motivating potential for math learning as aims to aid in the practice of teachers in the classroom. In order to conduct the survey, the basic ideas are search-lead author on the use history in mathematics education, the main research on the topic, as well as the insertion of the story in the form of texts in textbooks, course books and college books history of mathematics. For some scientific content high school math, proposed by the Curriculum in Motion was made a historical overview on the subject, highlighting: its main mentors, the context in which it was designed, applications and curiosities, when deemed relevant to the topic of understanding. It is believed in the potential of the texts as a teaching resource in order to provide context and meaning to student learning, motivate students' interest in mathematics, get more significant results in the teaching-learning process of mathematics content.
\end{abstract}

Keywords: History in mathematics. Educational resource. Practice. High School. Mathematics teaching. 


\section{Sumário}

1 INTRODUÇÃO 1

2 USO DA HISTÓRIA DA MATEMÁTICA NO ENSINO 6

2.1 História do ensino da matemática no Brasil . . . . . . . . . . . . 6

2.2 Ensino-aprendizagem da matemática . . . . . . . . . . . . . . . . . 9

2.3 Bases legais e suas orientações . . . . . . . . . . . . . . . . . . . . 10

2.4 História da matemática como recurso didático . . . . . . . . . . . . . 16

2.5 Algumas produções que utilizam a história da matemática como recurso didático ........................... 17

3 OS TEXTOS COM HISTÓRIA DA MATEMÁTICA 19

3.1 Noções de matemática Financeira . . . . . . . . . . . . . . . . . 20

3.2 Conjuntos numéricos . . . . . . . . . . . . . . . . . . . . . 23

3.3 Função . . . . . . . . . . . . . . . . . . . . . . . . . . . . . 27

3.4 Geometria plana . . . . . . . . . . . . . . . . . . . 29

3.5 Matrizes e Sistemas lineares . . . . . . . . . . . . . . . . . . . 32

3.6 Sequências e Progressões . . . . . . . . . . . . . . . . . . . . . 36

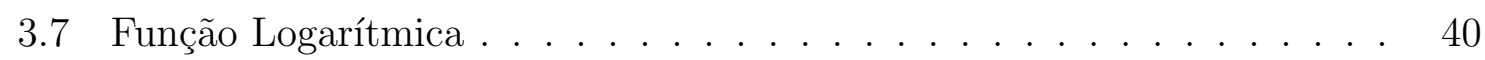

3.8 Trigonometria . . . . . . . . . . . . . . . . . . . . . . . . 42

3.9 Geometria espacial . . . . . . . . . . . . . . . . 46

3.10 Geometria analítica . . . . . . . . . . . . . . . . 48

4 UMA PESQUISA EMPÍRICA: OPINIÃO DE PROFESSORES SOBRE HISTÓRIA NO ENSINO

4.1 Metodologia de pesquisa empírica . . . . . . . . . . . . . . . 52

4.2 Resultados da pesquisa empírica . . . . . . . . . . . . . . 55

5 CONCLUSÃO $\quad 65$

$\begin{array}{ll}\text { REFERÊNCIAS BIBLIOGRÁFICAS } & 67\end{array}$ 
APÊNDICE 


\section{Lista de Figuras}

2.1 Matriz Curricular do Ensino Médio. . . . . . . . . . . . . . . . 15

3.1 Euclides. . . . . . . . . . . . . . . . . . . . . . . 31

3.2 Tabela do Campeonato Brasileiro - Séria A . . . . . . . . . . . . . 33

3.3 Árvores de carvalho . . . . . . . . . . . . . . . . . . . . 36

3.4 Aidan estudando a disposição dos galhos . . . . . . . . . . . . . . . . . . . . . . . . . . . . 37

3.5 Os dois projetos de coleta de luz . . . . . . . . . . . . . 37

3.6 Modelo típico de captação de luz solar . . . . . . . . . . . . . . . . . 38

3.7 Placas Tectônicas . . . . . . . . . . . . . . . . . . . . . . 41

3.8 Visão - Trigonometria . . . . . . . . . . . . . . . . . . . . 43

3.9 Miquerinos, Quéfren e Quéops _. . . . . . . . . . . . . . 47

4.1 Perfil dos professores entrevistados. . . . . . . . . . . . . . . . 55 


\section{Capítulo 1}

\section{INTRODUÇÃO}

De acordo com a página eletrônica do Programa de Mestrado Profissional em matemática em Rede Nacional (PROFMAT), o objetivo do mesmo é estimular a melhoria do ensino da matemática em todos os níveis. Este também é o propósito da autora desta dissertação desde quando entrou para graduação na Licenciatura em matemática na Universidade de Brasília (UnB) em 2009. A sua própria experiência como aluna durante a educação básica, predominantemente em escola pública, já a fazia refletir sobre o porquê da maioria dos seus colegas de classe apresentam dificuldade em aprender uma matéria tão prazerosa (para a autora) como a matemática.

O ingresso como professora na rede pública de ensino do Distrito Federal no ano de 2013 a fez considerar que a situação da relação que os alunos tinham com a matemática era mais crítica que pensava. São vários os fatores externos à matemática que contribuem para este quadro, como desinteresse, desmotivação, baixa produtividade, falta de apoio escolar por parte da família, falta de disciplina do alunado, falta de recursos, falta de infraestrutura da escola, desvalorização dos profissionais de educação, professores despreparados para lecionar, entre outros. Vale citar ainda os fatores inerentes à matemática: a maneira como é ministrada, isolada das outras disciplinas; poucas contextualizações e modelagens na abordagem dos conteúdos; exercícios limitados ao aspecto teórico e de memorização; exercícios relacionados mais à aplicação repetitiva de algoritmo.

Tudo isso contribui para o fracasso escolar, que era visto com destaque nos resultados em uma das disciplinas mais difíceis e temidas do currículo escolar: a matemática. As consequências do desenrolar da situação difícil e delicada encarada acima são: formar pessoas que aprendem pouco, que não entendem a importância do saber científico, que reprovam, que evadem a escola, e por fim criam um cidadão sem perspectiva de vida que faz parte de uma massa que não questiona e que se conforma.

Muito preocupada com o rumo que a educação da matemática estava percorrendo, a autora procurou meios de se aperfeiçoar com relação aos conteúdos matemáticos com o desejo de contribuir mudar este lamentável quadro. A autora acredita 
que, dentre outros requisitos, o professor precisa ter um exímio domínio da disciplina que leciona para dar uma boa aula. O PROFMAT era justamente o que procurava, pois no programa havia um cronograma de disciplinas adequadas e relevantes que se relacionava com a prática docente do ensino básico, a turma do mestrado que era composta por colegas, em sua maioria, professores possuidores de uma carga de experiência profissional riquíssima, pronta para ser compartilhada e os competentíssimos professores do Departamento de matemática da Universidade de Brasília. O ingresso aconteceu em 2014.

Não demorou muito para perceber que o excepcional entendimento dos conteúdos por parte do docente era essencial, mas não o único fator para que os alunos pudessem compreender melhor a matemática; era necessário fazer com que eles se interessassem, estivessem motivados e mostrassem vontade de aprender mais. A bagagem intelectual carregada durante o curso de graduação e a práxis em regência de classe a fez notar que quando a história da matemática relacionada a determinado conteúdo é apresentada aos alunos durante, ou antes, da explanação da aula, eles ficam mais atentos e se mostram mais curiosos.

Muito se faz em prol da qualidade da educação matemática. Atualmente é notável a quantidade de entidades nacionais e internacionais, que atuam neste âmbito, como por exemplo: Instituto de matemática Pura e Aplicada (Impa), Mathematical Association of America (MAA), Sociedade Brasileira de Educação matemática (SBEM) e Sociedade Brasileira de Matemática (SBM). Estas organizações colaboram de maneira significativa para o aprimoramento do ensino da matemática através do estímulo às atividades de pesquisa e estudos acadêmicos, para a difusão de conhecimentos e experiências por meio de eventos e para a oferta de cursos que visam contribuir para a formação profissional do professor na área de educação matemática.

São observadas na literatura muitas pesquisas em educação matemática com propostas de alternativas metodológicas e estratégicas para tornar a aprendizagem dos alunos satisfatória. Há muitos trabalhos publicados sobre a história da matemática, como apoio e com uso direcionado à sala de aula, que podem auxiliar na compreensão do conhecimento. Para Britto e Bayer (2007) falar de história leva a pensar em narração de fatos e acontecimentos ocorridos na evolução das sociedades. Não se pode esquecer que o hoje é resultado das revoluções mentais, sociais, físicas e climáticas de ontem. O ontem é o ocorrido, às vezes, documentado, ou mesmo transmitido oralmente e que assim se transforma em história.

Ferreira (apud MENDES, 2001) aponta a característica principal das atividades de ensino de matemática apoiadas na história: devem utilizar a percepção do aluno, levá-lo à verbalização das ideias percebidas para, em seguida, orientá-lo nas representações simbólicas de acordo com a estrutura cognitiva.

Dambros (2006) afirma que o professor que conhece a história da matemática 
compreende a matemática como uma ciência em progresso e construção, como uma criação conjunta da humanidade e não como uma ciência pré-existente, um presente acabado de Deus, descoberta por gênios e por isso incontestável. Alguns pesquisadores vão além, alegando que essas duas concepções da matemática, além de poderem ser determinadas pelo conhecimento histórico, influenciam diretamente a prática pedagógica do professor. Dessa forma Britto e Bayer (2007) assentam que, a partir dos conhecimentos de História da matemática, é possível adquirir melhor compreensão do conteúdo matemático fazendo utilização do caminho de como se chegou aos conhecimentos atuais. Isso ocorre porque estudar desde a necessidade que levou o homem, em uma determinada época, a pensar sobre determinado assunto, até as aplicações práticas, tornariam o aluno motivado. Além disso, Lopes e Alves (2014) destacam que o resgate da história dos saberes matemáticos ensinados no espaço escolar traz a construção de um olhar crítico sobre o assunto em questão, proporcionando reflexões acerca das relações entre a história cultural e as tecnologias.

Os documentos oficiais que orientam a organização do currículo escolar trazem o entendimento de que é aconselhável inserir a evolução do conhecimento para dentro da sala de aula no campo de matemática. Os Parâmetros Curriculares Nacionais para o Ensino Médio?PCN (BRASIL, 2010) orientam que a aula de matemática seja pautada, dentre outros fatores, na constituição de habilidades e competências que permitam ao educando: compreender as ciências como construções humanas, entendendo como elas se desenvolvem por acumulação, continuidade ou ruptura de paradigmas, relacionando o desenvolvimento científico com a transformação da sociedade. Quanto ao que se adequa ao uso da história no ensino de matemática, esse documento recomenda ao professor, nos estudos na área de Ciências da Natureza, matemática e suas Tecnologias, levar em conta que a matemática é uma construção humana histórica e que os objetos de estudo por ela construídos, mais os discursos por ela elaborados, fazem parte da maneira de como a sociedade olha para o presente e tem a perspectiva do futuro.

A maior parte dos professores de matemática atuante na área não usa a história da matemática como ferramenta em suas aulas. Vários fatores podem justificar essa realidade. Através de uma pesquisa acerca do tema e análise das informações coletadas, Menezes (2014) conclui que: 
Os resultados mostraram que os professores valorizam a história no processo ensino-aprendizagem, mas consideram que as circunstâncias que envolvem o contexto do seu trabalho contribuem para não efetivarem a inserção desta tendência em sua prática. Em geral, alegam que não tiveram esta experiência em sua formação profissional, não recebem orientação nem no ponto de vista da formação continuada, nem nas orientações do livro didático para o professor, mesmo que este recurso insira a história em suas páginas, assim não concretizam essa valorização em sua prática. (TEXTO NÃO PUBLICADO)

Britto e Bayer (2007) também fizeram a investigação sobre o uso da história da matemática no ensino e as suas interpretações ratificaram a posição dos entrevistados sobre o tema:

Quando questionamos os docentes quanto ao uso da História da matemática em suas práticas, verificamos que os mesmos consideram este recurso importante, mas não têm o hábito de utilizá-lo em suas abordagens. Este fato é justificado por não estarem preparados para utilizar este recurso e o mesmo não constar nos currículos escolares, bem como também haver falta de material para auxiliá-los a desenvolver tal proposta (p. 61).

Os livros didáticos atuais de matemática usados no Ensino Médio pelos docentes e discentes adotados no Distrito Federal, quando abordam a história da matemática, normalmente limitam-se a curtas biografias de matemáticos famosos de forma pontual, ou alguma informação cronológica de caráter ornamental e não investigativo. Não foi observado pela autora um livro didático do Ensino Médio que tivesse a história da matemática como uma construção do conhecimento em questão, pois é sabido que a evolução de tal tema não foi uma nem duas pessoas envolvidas, mas sim vários sujeitos, em localizações geográficas distintas, em campos de saberes diversos, em épocas dessemelhantes, e que leva a sociedade ao marco que a está hoje: parte de um imenso edifício matemático inacabado do qual é necessário aprender como a base foi criada, ou seja, como conhecimento evoluiu desde a sua gênese, para compreender e dar a contribuição na construção do enorme monumento.

A forma de organização atual dos conteúdos de matemática para o Ensino Médio das escolas do Distrito Federal já foi amplamente discutida durante várias plenárias da qual participaram professores da educação básica e comunidade escolar. Durante o quadriênio 2010/2013 foi coletado, discutido e amplamente argumentado o documento orientador para a organização curricular e referências de conteúdos do Distrito Federal para assegurar uma formação básica comum: Currículo em Movimento. 
A escolha deste documento como norteador desta dissertação ocorreu porque a autora atua na Secretaria de Estado de Educação do Distrito Federal (SEDF).

Apesar de todos esses esforços, pouco se conhece sobre a contribuição de textos em história da matemática com propósitos motivadores para o Ensino Médio. Portanto, o objetivo de estudo escolhido neste trabalho é a produção de textos motivadores sobre tópicos da história da matemática para os alunos da última etapa da educação básica. A proposta para minimizar a problemática é fornecer ao professor de matemática desta etapa escolar um recurso didático adicional que o auxilie na prática escolar a fim de que cresça a motivação e a vontade de aprender por parte dos alunos.

Assim sendo, o objetivo geral deste trabalho é construir uma coletânea de textos sobre a história da matemática direcionados para uso do professor em sua prática pedagógica, a qual contenha um apanhado histórico distribuído cronologicamente e organizado acerca dos conteúdos do Ensino Médio, seguindo as orientações do Currículo em Movimento. Os professores poderão usar como referência de apoio didático e que seja a possível solução a fim de que o uso da história no ensino de matemática para alunos do Ensino Médio seja expandido para todas as escolas. Já os objetivos específicos são: a) fazer pesquisas bibliográficas a respeito da história da matemática direcionada aos conteúdos recomendados para o Ensino Médio; b) mostrar a validade e a importância do uso dos textos como recurso motivador na sala de aula por meio de uma pesquisa empírica junto a professores sobre o assunto. O professor que decidir fazer uso deste material pode tomar como referência os textos aqui inseridos, fazer uso das considerações sobre o tema que estão na parte final de cada texto e das referências bibliográficas para aprofundar o conhecimento acerca do assunto específico do texto, iniciar discussão direcionada em torno do assunto, e que finda na formalização do conhecimento, através de atividades que englobam o conteúdo programático previsto no plano de curso.

A estrutura desta dissertação é composta por três capítulos. No primeiro capítulo, é apresentada a fundamentação teórica, em que o foco é o uso da história no ensino de matemática. Além disso, serão abordados a história do ensino da matemática no Brasil, ensino-aprendizagem da matemática, bases legais e suas orientações, história da matemática como recurso didático e algumas produções que a utilizam como recurso didático. O capítulo seguinte é dedicado ao produto da dissertação, o conjunto de textos, bem como a metodologia e os procedimentos empregados para a obtenção dos mesmos. O último capítulo trata da averiguação, perante professores de matemática, da aplicabilidade dos textos na sala de aula. Finalmente, serão apresentadas as conclusões e perspectivas de futuras pesquisas, seguido das referências, do apêndice. 


\section{Capítulo 2}

\section{USO DA HISTÓRIA DA MATEMÁTICA NO ENSINO}

Várias considerações relevantes que envolvem o uso da história no ensino de matemática são tratadas neste capítulo, de modo que se construa com o leitor o embasamento para o uso desta estratégia de ensino, a história da matemática. O primeiro tópico trata da investigação dos fatos históricos que mais influenciaram o ensino de matemática no Brasil e é de suma importância para entender como aconteceu a evolução da educação matemática brasileira e de que forma isso impacta no sistema de ensino que se tem hoje no Brasil. O próximo item aborda a caracterização das duas principais correntes pedagógicas norteadoras do processo ensino-aprendizagem da matemática, tradicional e construtivista, com o objetivo de levar ao conhecimento do leitor o funcionamento da dinâmica na sala de aula. O terceiro tópico item analisa os documentos legais que versam sobre o ensino da matemática e como pode ser introduzida a história na aula de matemática se embasando nas orientações presentes nas bases legais. O quarto item trata das finalidades em se usar a história da matemática, na percepção de alguns autores. Por fim, o último tópico mostra algumas produções publicadas que utilizam a história da matemática como recurso didático.

\subsection{História do ensino da matemática no Brasil}

Durante o período colonial, o ensino de matemática no Brasil recebeu tratamento semelhante às ideias positivistas propagadas em Portugal. Nesta época Portugal tornou a disciplina de matemática obrigatória em todos os cursos da Universidade de Coimbra, além de criar a Faculdade de matemática e regulamentar a profissão de matemático. Essa atenção que foi dada à matemática pelos portugueses inspirou a criação em 1810 da primeira instituição, Academia Militar do Rio de Janeiro, dedicada a conhecimentos utilitaristas e científicos tendo a matemática como disciplina principal. 
O positivismo, sediado na Europa, do filósofo e matemático francês Augusto Comte (1798 - 1857) no início do século XIX, encontrou condições propícias para ingressar no Brasil: ascensão da burguesia e profissões intelectuais. A porta de entrada do positivismo no Brasil foi através da matemática que estava começando a ser ensinada na Academia Militar do Rio de Janeiro.

Uma das principais obras de Comte é o "Curso de Filosofia Positiva", em seis volumes, publicados entre 1830 e 1842. Em sua Filosofia Positiva, Comte aplica às ciências sociais os métodos racionais utilizados na matemática para extrair as leis que regem o desenvolvimento da sociedade, atribuindo um papel social à ciência. Assim, o positivismo busca classificar todos os fenômenos por meio de um reduzido número de leis naturais e invariáveis, sendo que o estudo dos fenômenos deve começar dos mais gerais ou mais simples e a partir deles conseguir a ordenação nas ciências, até alcançar os mais complicados ou particulares (MOTTA \& BROLEZZI, 2006, p. 4661).

O ensino positivista influenciou a educação brasileira, não só na esfera militar, mas também nos demais setores, incluindo o ensino superior, durante todos esses séculos até a primeira metade do século seguinte.

O ensino de matemática nos meios acadêmicos do Brasil passou por transformações significativas na década de 60, através do Movimento da matemática Moderna (MMM), impulsionadas pela insatisfação com o ensino da matemática vigente na época. Antes deste período, promoveram-se os primeiros encontros com foco na educação matemática: os Congressos Nacionais de Ensino de Matemática sediados em Salvador, Porto Alegre e Rio de Janeiro em 1955, 1957 e 1959 respectivamente. Pelos anais desses congressos e teses publicadas na época sobre o tema, é notada uma tímida abordagem sobre as ideias modernistas da matemática.

Em todos estes movimentos discutiu-se sobre currículo, aperfeiçoamento dos professores de matemática, e livros didáticos; recomendou-se a eliminação do ensino demasiadamente abstrato e a promoção da matemática contextualizada e aplicada aos outros componentes curriculares do antigo curso secundário. O MMM foi explicitamente tratado no IV Congresso Nacional de Ensino de matemática ocorrido em Belém no ano de 1961, objetivando a valorização da matemática através de reforma no currículo escolar com a inserção dos tópicos: Teoria dos Números, Lógica Matemática, Teoria dos Conjuntos e Álgebra Moderna em todos os graus nas instituições de ensino brasileiras.

Nos Congressos Nacionais de Ensino de Matemática, os debates eram predominantemente a respeito de adição e subtração de componentes curriculares. As práticas metodológicas do ensino da matemática receberam atenção em alguns grupos 
de estudos difusores da matemática Moderna, organizados em alguns estados brasileiros, posteriores aos congressos. Nota-se que o MMM quis instituir que a matemática acompanhasse a modernidade, no sentido de utilizar a matemática avançada aplicada à evolução tecnológica que estava ocorrendo.

Nos grupos de estudos formados a partir do MMM, a preocupação sobre a maneira como os conteúdos estavam sendo lecionados nas escolas, no nível atualmente denominado de ensino básico, por parte dos educadores matemáticos tomou grandes proporções. Vários estudos foram discutidos acerca do currículo do curso de matemática na formação dos professores relacionando o quão didático eram as aulas de matemática e qual era o impacto no aprendizado dos alunos. A maioria dos pesquisadores chegou ao consenso de que o currículo do curso de matemática poderia ser modificado para melhor preparar o professor, a fim de que ele tenha uma postura mais didática na sala de aula, impactando positivamente no processo de aprendizagem dos alunos.

A formação acadêmica dos professores de matemática, nas Instituições de Ensino Superior, começou a sofrer transformações significativas no currículo a partir do ano 1961 com a vigência da Lei no 4.024, de 20 de dezembro de 1961, primeira Lei de Diretrizes e Bases da Educação Nacional (LDBEN). Dentre outras normas educacionais, a LDBEN instituiu a criação do curso específico de licenciatura em matemática. Além de desobrigar o universitário a cursar bacharelado em matemática com complementação em pedagogia para tornar-se professor, a primeira LDBEM estabeleceu as disciplinas relacionadas ao ensino que deveriam ser cursadas concomitantemente com as disciplinas específicas da matemática.

Um aspecto desfavorável da divisão do curso em licenciatura e bacharelado é que, reduziu-se gradativamente até a metade as disciplinas ligadas à pedagogia na formação do professor. A primeira LDBEM propôs um sistema educacional engessado que recebeu muitas críticas na época. A Lei 5.540/68, que ficou conhecida como Lei da Reforma Universitária, deu maior flexibilidade na organização dos cursos superiores e serviu de base para reestruturar a Lei de Diretrizes e Bases da Educação nos anos posteriores. Na prática, as instituições de ensino superior tenderam a inserir e ampliar disciplinas dedicadas ao ensino. As disciplinas de matemática abstrata consideradas muito avançadas e pouco relevantes para o curso de licenciatura sofreram redução na grade curricular do curso.

Após a modificação na estrutura do currículo da licenciatura, guardado o período de observações, infelizmente foi observado que a maioria dos alunos da educação básica continuou com proficiência insatisfatória em matemática. Percebese isso de acordo com a análise dos resultados obtidos entre algumas provas de larga escala no âmbito do componente curricular matemática. O interesse de melhorar o ensino-aprendizagem com relação a matemática dos alunos do ensino básico continua 
sendo a preocupação de professores-pesquisadores como Ubiratan D'Ambrósio, Iran de Abreu Mendes e Eduardo Sebastiani Ferreira. Diversos materiais foram publicados, vários eventos foram e ainda são produzidos para reunir pessoas interessadas em contribuir para a melhoria do ensino da matemática.

Atualmente, uma atividade de grande expressão, o Mestrado Profissional em matemática em Rede Nacional (PROFMAT), no que se refere à educação matemática, é coordenado pela Sociedade Brasileira de matemática (SBM) e consiste em um curso semipresencial com oferta nacional para aperfeiçoamento dos professores de matemática do ensino básico. Em sua apresentação, o

PROFMAT visa atender professores de matemática em exercício no ensino básico, especialmente na escola pública, que busquem aprimoramento em sua formação profissional, com ênfase no domínio aprofundado de conteúdo matemático relevante para sua atuação docente. O Programa opera em ampla escala, com o objetivo de, a médio prazo, ter impacto substantivo na formação matemática do professor em todo o território nacional. (PROFMAT, 2016)

Foi este Programa que oportunizou a autora aprofundar a bagagem acadêmica e conceber a dissertação que está sendo produzida.

\subsection{Ensino-aprendizagem da matemática}

Considerando o ensino como uma prática pedagógica que visa ao aprendizado do aluno, o processo de ensino-aprendizagem é um fenômeno educativo que envolve três protagonistas: professor, aluno e o conhecimento, no qual o professor, às vezes, é visto como o detentor absoluto do conhecimento que transmite para o aluno, outrora se comporta como o mediador entre o aluno e o conhecimento. Nas escolas, é percebido que o trabalho pedagógico que o professor executa, na maioria, segue duas correntes pedagógicas: tradicional e construtivista.

O método tradicional de ensino ainda é o mais presente nas aulas de matemática. Esta corrente é caracterizada pela transmissão de conhecimento através da exposição verbal por parte do professor que normalmente apresenta o conteúdo, relaciona com outros assuntos, faz a generalização e por último aplica exercícios. O aluno por sua vez age como um receptor de conhecimentos, memorizando fórmulas e conceitos. Caso os alunos estejam motivados e atentos, a chance de sucesso no processo é alta, já que a condução da aula depende somente do professor, e ele pode atingir a maioria dos alunos ao mesmo tempo com esta estratégia. É observado que os alunos não costumam ter esta postura na sala de aula. 
A segunda corrente, que não é tão expressiva quanto a tradicional, busca delegar ao aluno a grande parte da responsabilidade pelo conhecimento que será adquirido durante as aulas, ou seja, participar ativamente do processo ensino-aprendizagem sendo o protagonista. Nas ideias construtivistas da aprendizagem, o professor é responsável por criar situações que estimulem a construção do conhecimento pelo próprio aluno, ou seja, o professor atua como um mediador, proporcionando confronto dos conhecimentos pré-existentes com o novo. O construtivismo, dentre suas vantagens, procura tornar o aluno autônomo quanto à construção do próprio conhecimento, tornando-o prazeroso. Todavia, em vista da ampla variedade de situações que podem ser constatadas no sistema escolar, ainda falta aprofundar os estudos que permitam estabelecer uma sistematização da tendência construtivista de ensino.

Cada corrente pedagógica traz consigo suas particularidades caracterizando suas vantagens e desvantagens. Ainda hoje, não foi definida as maneiras que melhor se adéquam à dinâmica das aulas de matemática, pois depende muito da reflexão que o professor faz sobre as suas práxis na escola. Contudo, é definido o objetivo que se deve alcançar com o ensino-aprendizagem de matemática após a última etapa da educação básica de acordo com as Orientações Curriculares para o Ensino Médio:

(...) espera-se que os alunos saibam usar a matemática para resolver problemas práticos do quotidiano; para modelar fenômenos em outras áreas do conhecimento; compreendam que a matemática é uma ciência com características próprias, que se organiza via teoremas e demonstrações; percebam a matemática como um conhecimento social e historicamente construído; saibam apreciar a importância da matemática no desenvolvimento científico e tecnológico. (BRASIL, 2006, p. 69)

Essa ideia reforça a importância da história como elemento de composição no ensino básico, no que se refere à matemática.

\subsection{Bases legais e suas orientações}

Esta sessão trata da investigação de documentos oficiais nacionais que legislam sobre a educação básica, como a Constituição Federal, a lei № 9.394/96, as Orientações Curriculares Nacionais e o Currículo em Movimento. Com atenção voltada para o olhar do Estado quanto ao Ensino Médio, juntamente com a escolha dos conteúdos que constituem o componente curricular matemática. Nas observações das orientações, a importância da utilização de metodologias que ajudam os alunos compreenderem os conteúdos é posta em destaque, infere-se que a história da matemática pode ser um elemento que ajuda na contextualização dos conteúdos, como indicado para ser colocado em prática na sala de aula. 
A escola é o principal lugar de sistematização do conhecimento produzido pela humanidade, embora a produção intelectual e o transporte de informações através da tecnologia tenham avançado muito. A escola por si só não garante a transformação social dos cidadãos, mas sem dúvidas é o meio que pode ampliar as condições de inclusão social, ao possibilitar o acesso à ciência, à tecnologia, à cultura e ao trabalho. De acordo com os Parâmetros Curriculares Nacionais,

A educação, por meio da escolarização, consolidou-se nas sociedades modernas como um direito social, ainda que não tenha sido universalizada. Concebida como forma de socializar as pessoas de acordo com valores e padrões culturais e ético-morais da sociedade e como meio de difundir de forma sistemática os conhecimentos científicos construídos pela humanidade, a educação escolar reflete um direito e representa componente necessário para o exercício da cidadania e para as práticas sociais. (BRASIL, 2010, p. 150)

Como dever do Estado e realidade social, a educação é abordada em vários documentos legais. Esses textos mostram, em sentido geral, a preocupação que a sociedade tem com o direito dos cidadãos ao acesso ao ensino de qualidade.

Através da Declaração Universal do Direitos Humanos, representantes do mundo todo, em 1948, assumiram o compromisso de garantir o direito à educação de todas as pessoas, a fim de desenvolver a capacidade de compreensão dos direitos de outrem, oportunizar a tolerância e a amizade entre os povos do mundo inteiro almejando a paz mundial.

No âmbito nacional, a garantia à educação é um direito social estabelecido no art. 6 da Constituição da República Federativa de 1988. Embora o texto constitucional expressa um capítulo completo (art. 205 ao art. 214) a respeito da educação, é percebida a matéria de forma muito abrangente e objetiva. Antes da promulgação da Lei Maior vigente, existia uma lei exclusiva destinada a diretrizes e bases da educação. Com o aumento da relevância atribuída, de forma inovadora, à educação na nova constituição, a lei específica sobre a matéria educacional sofreu alterações para direcionar a uma autêntica legislação educacional que efetiva os pressupostos contidos na Constituição de 1988 dando origem à Lei Nº 9.394/96, de Diretrizes e Bases da Educação Nacional (LDB).

No que se refere à Educação Básica, a LDB destaca o dever dos Estados e do Distrito Federal de oferecer, com prioridade, o Ensino Médio a todos que demandarem (artigo 10, inciso VI). Além disso, a LDB, no inciso IV do seu artigo $9^{\circ}$, versa sobre a atribuição da União em estabelecer competências e diretrizes para a Educação Básica, que nortearão os currículos e seus conteúdos mínimos, de modo a assegurar formação básica comum. 
A LDB estabelece, ainda, em seu art. 22, que a Educação Básica tem por finalidade desenvolver o educando, assegurar-lhe a formação comum indispensável para o exercício da cidadania e fornecer-lhe meios para progredir no trabalho e em estudos posteriores.

O currículo, na perspectiva educacional, é compreendido como a seleção de conhecimentos acumulados, considerados importantes para o desenvolvimento da sociedade. Com embasamento legal exposto no inciso IV, artigo $9^{\circ}$ da LDB, as Diretrizes Curriculares Nacionais Gerais para a Educação Básica, elaboradas pelo Conselho Nacional de Educação (CNE), cumprem o dever de orientar o sistema educacional brasileiro para que ele assegure um currículo comum e uma formação básica aos cidadãos, ressaltando a coexistência da parte diversificada do currículo, que varia de acordo com a realidade social e com os propósitos da Plano de Políticas Pedagógicas de cada instituição de ensino.

As Diretrizes Curriculares Nacionais para o Ensino Médio (DCNEM, 2013) no artigo $8^{\circ}$, estabelecem que o currículo seja organizado em quatro áreas do conhecimento: Linguagens, Matemática, Ciências da Natureza e Ciências Humanas, sendo que todos os componentes curriculares obrigatórios previstos na LDB sejam tratados dentro das quatro áreas do conhecimento. O Currículo do Ensino Médio, no art. 12, deve:

II- adotar metodologias de ensino e de avaliação de aprendizagem que estimulem a iniciativa dos estudantes;

III- organizar os conteúdos, as metodologias e as formas de avaliação de tal forma que ao final do Ensino Médio o estudante demonstre:

a) domínio dos princípios científicos e tecnológicos que presidem a produção moderna;

b) conhecimento das formas contemporâneas de linguagem (p. 197)

As Orientações Curriculares para o Ensino Médio - OCEM (BRASIL, 2006) integram o documento que visa contribuir para discussões sobre as orientações curriculares em três perspectivas: a escolha dos conteúdos, a forma de trabalhar os conteúdos e o projeto pedagógico para a organização curricular. Este documento é um importante alicerce para o cumprimento de dispositivos constitucionais no que se refere aos conteúdos componentes do currículo para assegurar a formação básica comum dos cidadãos, propostos pela Constituição Federal, Lei de Diretrizes e Bases da Educação Nacional e as Diretrizes Curriculares Nacionais do Ensino Básico. Nessas orientações os conteúdos matemáticos integrantes da base comum curricular estão expressamente apresentados e acompanhados de uma espécie de assistência pedagógica. Os conteúdos estão divididos em quatro blocos: Números e operações; Funções; Geometria; Análise 
de dados e probabilidade. Sobre a investigação acerca de cada bloco, é proposto que o aluno adquira certas habilidades e competências; que é possível após o estudo de conteúdos específicos.

No que diz respeito aos conhecimentos de matemática, as Orientações Curriculares para o Ensino Médio recomendam que seja priorizada a qualidade do processo educativo e não a quantidade de conteúdo. Desta forma, aborda de maneira prática e didática sugestões de metodologias para a práxis do professor em sala de aula. Dentre as maneiras sugeridas de como contextualizar, conectar o conteúdo com outras áreas do conhecimento e fazer uso da modelagem matemática, as Orientações Curriculares para o Ensino Médio recomendam o uso da história da matemática como elemento motivador, por atribuir significados aos conceitos matemáticos e entender como a construção do conhecimento ocorreu através da sua história, além de ser um importante elemento de contextualização.

As secretarias de educação dos estados atuam em regime de cooperação com os entes Federais responsáveis pela elaboração do currículo de base comum nacional. Isso ocorre porque se entende que cada região do país possui suas peculiaridades e elas podem ser observadas mais cuidadosamente pela entidade que faz o acompanhamento cotidiano com o objetivo de tornar o currículo um instrumento eficaz para o sucesso das práticas escolares.

A Secretaria de Estado e Educação do Distrito Federal (SEDF), juntamente com professores da escola pública do Distrito Federal, propôs uma organização curricular integrada e condizente com os instrumentos constitucionais que legislam sobre a educação. Obtiveram como resultado a elaboração do Currículo em Movimento, que tem seus objetivos expressos (DISTRITO FEDERAL, 2012).

Assim, com o intuito de que este Currículo seja percebido muito mais como documento orientador e de reflexão, e menos com o histórico caráter prescritivo que os currículos geralmente são vistos, a SEDF tem como objetivo principal promover uma reorganização do espaço/tempo escolar e da proposição de estratégias metodológicas que favoreçam a efetividade do processo de ensino e aprendizagem, da pratica docente e das relações professor-estudante, com vistas a melhoria dos indicadores educacionais. Os objetivos específicos deste currículo são: 
- Melhorar as condições pedagógicas por meio da reorganização do tempo/espaço do cotidiano escolar.

- Reduzir os índices de reprovação e evasão escolares.

- Tornar mais efetiva a relação professor-estudante.

- Qualificar a avaliação, incluindo o processo contínuo de recuperação das aprendizagens.

- Redimensionar a coordenação pedagógica como um espaço/tempo de planejamento, troca de experiências, pesquisa e formação continuada dos professores. (p. 15)

A matemática como componente curricular obrigatório estabelecido pela LDB, apresentada como uma área do conhecimento de acordo com as DCNEM, possui uma matriz curricular expressa no Currículo em Movimento, que orienta a práxis nas escolas públicas do Distrito Federal.

De acordo com a Lei de Diretrizes e Bases da Educação Nacional, o Ensino Médio tem como meta o aprofundamento de conhecimentos adquiridos no Ensino Fundamental e, o desenvolvimento da autonomia intelectual e do pensamento crítico formar cidadãos éticos e autônomos, capazes de compreender os processos produtivos. Assim sendo, o Currículo em Movimento legitima o desejo de que o ensino da matemática fortaleça o pensamento crítico e que seja trabalhado de forma a levar o estudante a reflexão, desenvolvendo o pensamento crítico, auxiliando na resolução de problemas e no envolvimento em contextos sociais, culturais e econômicos (DISTRITO FEDERAL, 2014, p. 42).

O Currículo em Movimento apresenta de forma efetiva os objetos de estudos que deverão ser realizados nas escolas de Ensino Médio do Distrito Federal. Mais adiante, apresenta-se o quadro que transcreve os conteúdos da Matriz Curricular do Ensino Médio referente à matemática.

O professor de hoje conta com uma gama de documentos norteadores que ajudam na prática escolar. Sabe-se que todas essas leis muito bem elaboradas e discutidas nada significam se o professor não tomar para si a missão de ser um pilar na construção de uma educação de qualidade. É a partir dessas orientações que a elaboração de projetos educacionais promoverá uma educação de qualidade.

Cabe aos professores, portanto, contribuir de modo efetivo para a concretização desses projetos que compõem as políticas públicas, de forma a colaborar para o desenvolvimento da sociedade por meio da educação, incentivando a produção do conhecimento nas escolas, produzam cidadãos protagonistas e críticos.

Entende-se que a sociedade, através da constituição de bases legais em termos da educação escolar, orienta, pela busca do aperfeiçoamento do ensino através de 
métodos que estimulem o processo de ensino-aprendizagem, a direção que se pretende seguir.

\begin{tabular}{|c|c|c|}
\hline $1^{\mathrm{a}}$ ano & $2^{\mathrm{a}}$ ano & $3^{\mathrm{a}}$ ano \\
\hline $\begin{array}{l}\text { •Noções de matemática Financeira: } \\
\text { Razão, proporção, porcentagem; } \\
\text { Juros simples e compostos; } \\
\text { Descontos; Taxas e Financiamentos. }\end{array}$ & $\begin{array}{l}\text { •Matrizes: Aplicações com } \\
\text { matrizes; Operações; } \\
\text { Determinante de uma matriz. } \\
\text { •Sistemas Lineares: Formas } \\
\text { lineares, escalonados, } \\
\text { equivalentes e homogêneos; } \\
\text { Tipos de soluções: regra de } \\
\text { Cramer, escalonamento e outros. } \\
\text { •Sequências e Progressões: } \\
\text { Sequências; Progressões } \\
\text { aritméticas e geométricas. }\end{array}$ & $\begin{array}{l}\text { •Análise Combinatória: Princípio } \\
\text { da contagem; Arranjos, } \\
\text { permutações e combinações. } \\
\text { •Probabilidade: Espaço amostral e } \\
\text { evento; Probabilidades. } \\
\text { •Noções de Estatística: Coleta de } \\
\text { dados; Variáveis; Construção de } \\
\text { tabelas e gráficos; Distribuição de } \\
\text { frequências; Médias estatísticas } \\
\text { (aritmética ponderada e } \\
\text { harmônica); Moda, mediana e } \\
\text { desvio padrão. }\end{array}$ \\
\hline $\begin{array}{l}\text { • Conjuntos: Revisão de conceitos } \\
\text { fundamentais; Conjuntos } \\
\text { numéricos; Intervalos; Resolução de } \\
\text { situações-problema. } \\
\text { • Funções: Definição; Gráficos de } \\
\text { funçôes; Crescimento e } \\
\text { decrescimento; Domínio e imagem } \\
\text { dos intervalos. } \\
\text { • Função Polinomial de } 1^{\circ} \text { Grau: } \\
\text { Definição e gráficos; Zero da função } \\
\text { e equação de } 1^{\circ} \text { grau; Construção de } \\
\text { gráficos, tabelas e quadros } \\
\text { utilizando informações do cotidiano. } \\
\text { - Função Polinomial de } 2^{\circ} \text { Grau: } \\
\text { Definição e gráficos; Zeros da } \\
\text { função e equação de } 2^{\circ} \text { grau; Estudo } \\
\text { da parábola. } \\
\text { - Inequações: Aplicações e } \\
\text { operações com inequações. }\end{array}$ & $\begin{array}{l}\text { •Revisão de Potencial. } \\
\text { • Função Exponencial: Equação } \\
\text { exponencial; Função } \\
\text { exponencial; Inequação } \\
\text { exponencial; Aplicação a } \\
\text { matemática financeira com uso } \\
\text { de calculadora científica; } \\
\text { Situações problemas. } \\
\text { •Função Logarítmica: Definição } \\
\text { de logaritmo e propriedades; } \\
\text { Equações logarítmicas; } \\
\text { Definição de função logarítmica; } \\
\text { Representação gráfica; } \\
\text { Inequações logarítmicas. } \\
\text {-Trigonometria: Razões } \\
\text { trigonométricas (seno, cosseno, } \\
\text { tangente e seus correspondentes } \\
\text { trigonométricos); Relações } \\
\text { trigonométricas; Funçoses } \\
\text { trigonométricas; Leis dos senos e } \\
\text { cossenos. }\end{array}$ & $\begin{array}{l}\text { •Números Complexos: Parte } \\
\text { imaginária e real; Operações com } \\
\text { números complexos; Aplicações } \\
\text { dentro do conjunto complexo. } \\
\text { •Polinômios: Função polinomial; } \\
\text { Valor numérico polinômio nulo; } \\
\text { Operações com polinômios; } \\
\text { Equações polinomiais (ou } \\
\text { algébricas). }\end{array}$ \\
\hline $\begin{array}{l}\text { •Revisão de Geometria: Estudo dos } \\
\text { polígonos; Propriedades e } \\
\text { classificação de figuras planas; } \\
\text { Áreas de figuras planas associadas à } \\
\text { área do retângulo; Semelhança de } \\
\text { triângulos; Traçado de bissetrizes, } \\
\text { medianas e mediatrizes com uso de } \\
\text { régua e compasso; Triângulo } \\
\text { retângulo: Relações métricas e } \\
\text { Teorema de Pitágoras; Polígonos } \\
\text { inscritos e circunscritos em uma } \\
\text { circunferência. }\end{array}$ & $\begin{array}{l}\text { •Geometria Espacial: Área da } \\
\text { superfície / planificação, volume } \\
\text { e secção das configurações } \\
\text { matemáticas: prisma, pirâmide } \\
\text { (tronco) e esfera. }\end{array}$ & $\begin{array}{l}\text {-Geometria Analítica: Estudo do } \\
\text { Ponto; Estudo da Reta; Estudo da } \\
\text { Circunferência. }\end{array}$ \\
\hline
\end{tabular}

Figura 2.1: Matriz Curricular do Ensino Médio.

(Fonte: DISTRITO FEDERAL, 2014).

A legislação educacional vigente propõe o currículo que deve ser seguido nas escolas do Distrito Federal. É fundamental que o professor, em sua prática pedagógica, perceba as mudanças sofridas na sociedade como um todo e tenha a capacidade de colocar os conteúdos propostos em um contexto moderno, para que ele tenha significado. 
A utilização da história da matemática no Ensino Médio é vista como estratégia para resgatar a importância e o interesse pela educação matemática.

\subsection{História da matemática como recurso didático}

A inserção da história na aula de matemática é objeto de estudos desde antes do século passado, embora este tema seja muito explorado, a reflexão sobre sua aplicabilidade, no sentido de investigar as formas de usar a história da matemática como estratégia de ensino, não impedindo o uso de outras estratégias. A história como potencial motivador ajuda o aluno compreender a matemática como um processo evolutivo desafiador e não isolado. É importante perceber a história da matemática na prática escolar como uma estratégia útil, para que os educandos compreendam a origem dos conceitos matemáticos e sua importância na vida da humanidade, ajudando na construção do conhecimento lógico.

Hasseler (apud MIGUEL, 1993) compara o potencial motivador da história como recurso didático a uma palestra, na qual o orador bem-sucedido intercala a história e a recreação com o tema principal que exige muita concentração do público, a fim de não tornar sua conferência cansativa. Ele recomenda que as aulas de matemática sejam conduzidas de forma similar, que os professores conheçam as histórias de grandes matemáticos e seus trabalhos, para usá-las como fator motivacional. Normalmente, a aula de matemática é pautada na explicação da teoria e resolução de exercícios, essa prática diária exige muito do intelecto do estudante, e a repetição monótona torna a aprendizagem de matemática uma atividade penosa. Durante a aula, ter momentos de descontração e curiosidade, aliados aos conceitos matemáticos funcionam como um recesso para o período de grande esforço que a mente está submetida.

O uso da história no ensino de matemática tem outras utilidades que ajudam no cognitivo do aluno. Nada impede de associar a história da matemática com outro recurso didático, como por exemplo, a resolução de problemas. O estudante pode desenvolver seu pensamento matemático através de problemas encontrados na história, gerando a contextualização tão privada pelo sistema de ensino atual.

Na visão de D'Ambrósio (2011), a história é um elemento motivador importante, visto que considera o conjunto de conteúdos matemáticos ministrados nas escolas obsoletos e fora do contexto moderno. O mesmo recomenda que os problemas históricos não sejam aprofundados, mas que sirvam para criar um caminho lógicomatemático, através do conhecimento da concepção e desenvolvimento das teorias e práticas matemáticas.

Já foi visto anteriormente que a história da matemática tem uma aplicabilidade ampla. Há divergências de educadores matemáticos quanto à melhor utilização da história da matemática no ensino. Não há apenas a história da matemática como 
recurso didático. Dentre as tendências utilizadas nas aulas de matemática, podemos destacar a história da matemática, etnomatemática, modelagem matemática, resolução de problemas, jogos matemáticos, investigação matemática e tecnologia da informação. Isto permite ao professor lidar com muitas possibilidades de atuação, de modo que a ele concerne decidir como fazer uso deste recurso didático, escolher e combinar maneiras que melhor auxiliem em suas práxis.

\subsection{Algumas produções que utilizam a história da matemática como recurso didático}

O uso da história da matemática como apoio pedagógico é protagonista na

literatura. É feita a seguir uma análise de algumas obras que mostram a importância do uso da história da matemática e outras obras que são materiais concretos que visam auxiliar na prática na sala de aula.

No livro intitulado "O uso da história no ensino da matemática: reflexões teóricas e experiências", publicado em 2001, o Professor Iran Abreu Mendes (autor da obra) aborda um embasamento teórico sobre a história da matemática aplicada ao ensino utilizando sua própria experiência e pesquisas feitas por outros professores da área de educação matemática. O clímax da obra é referente à descrição de sua experiência de implementar a metodologia de ensino utilizando a história da matemática nos conceitos trigonométricos. A obra possui referências bibliográficas riquíssimas e valiosas para que os professores interessados em fazer uso da história no ensino de matemática, possam se aprofundar no tema.

A coleção Vivendo a matemática da Editora Scipione é uma coletânea de livros paradidáticos que tem a pretensão, expressa nos próprios livros, de contribuir para um melhor conhecimento da matemática. Os autores convidam o leitor a conhecer e experimentar a matemática num formato mais dinâmico, abordando conceitos matemáticos estudados no Ensino Fundamental I com criatividade, por vários momentos utilizando a história da matemática para contextualizar o assunto estudado e para torná-lo mais interessante.

Fundamentos da matemática Elementar é uma coleção de 11 volumes. Essa coleção é considerada uma das mais completas fontes bibliográficas destinadas a estudantes em fase pré-vestibular que buscam aprofundar conhecimentos e a universitários que almejam recordar a matemática elementar. Além de teorias e exercícios, os volumes possuem uma carga de textos, que trata da História da matemática relacionada aos temas abordados. A quantidade, qualidade, extensão e relevância observada nos artigos sobre história da matemática dessa coleção superam muito a maioria das publicações que usam a história da matemática como elemento motivador. Infelizmente, a coleção Fundamentos da matemática Elementar não é usada pelos alunos do Ensino 
Médio como livros didáticos, provavelmente por apresentar uma matemática muito aprofundada para o nível que se encontram.

A matemática no nível universitário possui uma gama de excelentes publicações nacionais e internacionais a respeito da história da matemática. A obra Introdução à história da matemática, 2011 do inglês Howard Eves é uma obra referência e amplamente utilizada como fonte de consulta para professores e estudantes universitários que procuram aprofundar o conhecimento acerca da história da matemática. A história é narrada cronologicamente e normalmente separada por regiões geográficas. Além disso, cada capítulo é precedido por um texto motivador que situa a produção matemática no contexto social da época, o que permite ao leitor compreender melhor o desenvolvimento histórico das ideias.

Após esse livro, o autor publicou uma série paradidática intitulada Tópicos de história da matemática para uso em sala de aula, que conta com seis pequenos volumes, traduzidos por Hygino H. Domingues, em 1992. A série aborda números naturais e numerais, computação, geometria, álgebra, trigonometria e cálculo. Cada volume da série é referente a um tópico da matemática, que não exige pré-requisito e sua compreensão não depende dos outros volumes. Para o aprofundamento de temas da história da matemática esta coletânea é eficaz, porém, para uso direto pelos alunos do Ensino Médio, o tratamento da história da matemática dada a série é inadequada, no sentido de ser de difícil compreensão para alunos deste nível, mais adequada no Brasil no ensino superior.

Todos os trabalhos citados requerem um olhar mais voltado para o Ensino Médio no que se refere à história da matemática. 


\section{Capítulo 3}

\section{OS TEXTOS COM HISTÓRIA DA MATEMÁTICA}

Neste capítulo serão apresentados dez textos versando sobre tópicos da história da matemática voltados para o Ensino Médio. Será feita uma breve retomada da argumentação sobre a validade da história no ensino e passar-se-á aos textos em seguida.

A história da matemática é de suma importância para compreender como o conhecimento matemático se constituiu, quais foram os questionamentos que levaram a humanidade a resolver problemas práticos e teóricos que envolvem o uso da matemática em diversas localidades de tempo e espaço. Já foram mostrados em tópicos anteriores trabalhos exitosos e propostas de utilização da história da matemática em sala de aula do Ensino Médio. No entanto, foi constatado também que ainda não foram vistos trabalhos que propõem uso de textos em quantidade significativa. Essa foi mais uma razão que motivou a autora a considerar estes textos.

A seguir será apresentado um conjunto de textos com história da matemática para uso em sala de aula no Ensino Médio, que poderão ser usados em ações concretas propostas pelo professor e que visam despertar no aluno a motivação para a interação como o objeto do conhecimento matemático e também perceber seu significado.

A metodologia usada para criar o produto desta dissertação, conjunto de textos, deriva de um processo de busca, análise e investigação em livros, artigos, teses, dissertações e sites sobre a história da matemática e outros assuntos condizentes com os conteúdos propostos de matemática do Ensino Médio. A pesquisa é de natureza bibliográfica, porque a partir das leituras feitas foi construído um conjunto de textos que se propõe aplicar nas escolas de Ensino Médio para contribuir com a tentativa de solucionar a problemática do desinteresse pela matemática por parte dos alunos.

A forma de abordagem da problemática é considera qualitativa, devido à interpretação dos fenômenos no ambiente natural, que não poder ser calculada através 
da conversão de opiniões em números. No caso deste trabalho, a ideia futura, com vista exploratória, é usar os textos motivacionais de história da matemática para o ensinoaprendizagem de matemática. Esses textos têm a pretensão de serem interessantes para os alunos.

Ao final de cada texto encontram-se as considerações sobre o tema, nas quais há observações pertinentes ao assunto, e sugestões para a utilização do texto. Os textos podem ser reproduzidos para diversos fins, desde que seja citada a fonte.

Vale destacar que de acordo com a Matriz Curricular para o Ensino Médio no Distrito Federal, conforme o documento "Currículo em Movimento" referente à matemática, agrupa os conteúdos em 21 temas no total. Para esta dissertação, optouse por selecionar dez temas e produzir dez textos pelas razões expostas a seguir:

Primeiro, foram os temas com maior oferta e riqueza de informações históricas encontradas durante a pesquisa bibliográfica. Depois, os temas selecionados estão sempre presentes em listas de concursos, vestibulares e outras formas de seleção. Finalmente, existe quantidade de material que pode ser utilizado em atividades de ensino de matemática referentes a esses conteúdos.

Os textos foram elaborados e intitulados a partir dos conteúdos propostos para o Ensino Médio na disciplina de matemática no Currículo em Movimento para servirem como recurso didático adicional, que busca auxiliar o trabalho pedagógico do professor que decidir fazer uso deles.

Por fim, convém destacar que se pretende completar o conjunto de textos com outros referentes aos temas restantes para fins de submissão à publicação. Para que este produto final seja o melhor possível, optou-se por agregar, à versão final, as sugestões advindas da apreciação deste trabalho, incluindo os resultados da pesquisa empírica que serão mostrados no próximo capítulo.

\subsection{Noções de matemática Financeira}

Para que estudar matemática financeira? Uma das razões bem fortes e convincentes é para não cair em "armadilhas" criadas por bancos, lojas e crediários. Eles "vendem a ideia" de que o bom negócio é atrelado a prestações pequenas em vista do prêmio adquirido. O comércio e a matemática financeira não eram como hoje; houve uma gradativa evolução ao longo de muitos anos em várias partes do nosso planeta.

A sociedade primitiva produzia todos os alimentos necessários para a sobrevivência de sua tribo. Não havia comércio. Com a evolução da comunicação entre comunidades, elas observaram que era muito vantajoso produzir certo alimento em excesso e trocar a sobra com outra tribo que fizera o mesmo procedimento, mas com um alimento diferente. O nome dessa troca é chamado de escambo. Nesse tipo de comércio primário o valor da mercadoria não era importante. 
A comunicação entre os indivíduos continuou evoluindo. As pessoas verificaram que era necessário um sistema de medidas (padrões fixos ou moedas) comum para tornar as trocas (não só de alimentos, mas também de objetos) um negócio justo. As sociedades que se assentam em diversas localizações geográficas em torno do mundo evoluíram o comércio de maneiras diferentes. Na Grécia Pré-helênica tem-se a primeira forma de comércio usando uma moeda, de que se tem notícia. Os gregos usavam o boi como padrão fixo para comercializar mercadorias, ou seja, o valor de cada produto era dado por certa quantidade de bois. Outras civilizações adotaram seus padrões fixos próprios, como: Sibéria, com a pele de animais; Ilhas do Pacífico, a pérola; Mali, a galinha; América Central pré-colombiana uma diversidade de padrões (cacau, algodão, cerâmica, pérolas, ouro e tecido).

Na China (século XVI - XI a.C.) houve o registro da moeda semelhante a que usamos hoje: o metal. Principalmente em peças de bronze que eram divididas em mesmo peso.

A troca de moedas por mercadorias começou a ser realizada no século VII a. C. provavelmente na Grécia e expandiu rapidamente pelos territórios vizinhos. Na fabricação das moedas eram usados pedaços de metais com a marcação do governo. Com a utilização de moedas na negociação de produtos, os centros comerciais gregos se desenvolveram e permaneceram em destaque até a consolidação do Império Romano. Roma usou a moeda para fazer negócios com o Oriente.

O comércio, no auge, Idade Média foi influenciado pelas grandes navegações ocorridas a partir do século XV. A troca de dinheiro por mercadorias ao redor do mundo fez surgir a figura do mercador, pessoa que realizava as transações comerciais entre países. Para fazer a conversão das mais diversas moedas, os mercadores estabeleciam uma cotação para o dinheiro de acordo com a quantidade de ouro que o país possuía. Algumas pessoas perceberam que podiam lucrar com a troca de moeda entre países, elas faziam o acúmulo de moedas desvalorizadas e as colocavam de volta no mercado quando acontecia a valorização. Enquanto isso, era comum que essas pessoas emprestassem um pouco do seu dinheiro armazenados, mas o devedor devolvia um volume de dinheiro maior do que lhe foi emprestado. O dinheiro não servia somente para facilitar a troca de mercadorias, mas também era uma forma de lucrar usando somente dinheiro.

Hoje, existem pessoas físicas e jurídicas que emprestam dinheiro. As instituições financeiras (bancos, financeiras, caixas econômicas, cooperativa de crédito, etc.) são pessoas jurídicas que têm o poder legal de emprestar dinheiro por tempo limitado para seus clientes. Os cidadãos comuns são pessoas físicas que também podem emprestar dinheiro e, inclusive, cobrar pelo empréstimo.

O pagamento de juros sobre o valor emprestado é o preço da cobrança do serviço de empréstimo via instituição financeira. Os juros são determinados pelo valor emprestado, prazo para pagamento, e a taxa de juros. 
Para um cliente saber qual instituição financeira oferece a maior vantagem sobre o crédito, é necessário analisar as taxas de juros ofertadas por elas. Quanto menor a taxa de juros, menores serão os juros e mais vantajoso será o empréstimo. As taxas de juros são calculadas levando em considerações vários fatores, dentre os quais os mais importantes, tem-se: os riscos da operação e o lucro. Os riscos da operação são baseados na inadimplência, ou seja, o perigo de não receber o dinheiro de volta. O lucro é o montante que deve sobrar após o pagamento de despesas necessárias para o funcionamento do estabelecimento (remuneração dos funcionários, energia, água, impostos, etc.).

Ao contrário que muitas pessoas pensam, não é crime o empréstimo de dinheiro entre cidadãos comuns, ao menos que haja cobrança de juros abusiva. O novo código civil estabelece que a taxa de juros máxima que pode ser cobrada é o dobro da taxa de juros Sistema Especial de Liquidação e de Custódia (Selic), esta é a taxa básica de juros do mercado e que está disponível para consulta na página eletrônica do Banco Central do Brasil (Bacen). A prática proibida por lei é conhecida por "crime de agiotagem", que é o ato de emprestar dinheiro com a cobrança de juros exorbitantes, isto é, aplicar uma taxa superior da que é fixada por lei para o cálculo de pagamento de juros.

Vários cuidados devem ser tomados com relação ao empréstimo de dinheiro. É interessante, para um cidadão comum que deseja emprestar dinheiro, elaborar um contrato mencionando todas as condições acordadas no negócio e buscar uma assistência jurídica que o auxilie na redução dos riscos. Já para uma pessoa que pretende tomar crédito, é aconselhável que ela reflita se o crédito é realmente necessário, analise o impacto que a nova dívida teria nas finanças pessoais, busque um credor confiável $e$ compare as taxas de juros oferecidas.

As instituições financeiras são credenciadas por órgãos competentes do governo que regulamentam e fiscalizam com rigor suas práticas. Todavia, os cidadãos comuns que emprestam dinheiro não têm seu exercício passível de fiscalização como as instituições financeiras. Esse fato faz com que pessoas oportunistas pratiquem o "crime de agiotagem". Além de cobrarem juros abusivos, geralmente os "agiotas" são caracterizados, por emprestarem dinheiro sem solicitar o comprovante de renda e exigem um "bem" como garantia. Caso a pessoa não pague o montante devido no tempo combinado, a divida aumenta rapidamente tornando insustentável. O acordo finaliza normalmente com a transferência do "bem" que serviu como garantia e que provavelmente vale muito mais que o valor do empréstimo. Em alguns casos o devedor recebe até ameaça de morte.

A educação financeira é a utilização consciente do dinheiro. O indivíduo que conhece a matemática financeira tem melhores oportunidades de avaliar as vantagens e desvantagens nas negociações cotidianas. 


\section{Considerações sobre o tema}

Os fatos passados mostram como a relação do dinheiro foi e é importante para o desenvolvimento da sociedade e o papel da matemática financeira neste contexto.

Sugestão de atividade: para aplicação desse texto em sala de aula, o professor pode disponibilizar o texto no formato impresso e pedir para que os alunos façam uma leitura inicial, a fim de que eles tomem contato com a construção da matemática financeira enquanto construção humana inacabada que impacta diretamente na vida das pessoas. Com isso, o professor pode abrir a discussão sobre o papel do dinheiro na evolução das civilizações e as vantagens e desvantagens de obter crédito com pagamento de juros. Após a discussão, pode reforçar a importância de estudar matemática financeira. O próximo passo será a aula expositiva sobre o assunto, e depois o professor pode apresentar situações problemas sobre o assunto situados no livro didático do aluno para a fixação do assunto.

Considera-se que o texto poderá contribuir para uma motivação inicial no estudo da matemática financeira, uma vez que aborda situações relativas ao cotidiano dos alunos, portanto inerentes à sua própria vivência. Além disso, como o aspecto financeiro e a economia afetam diretamente a vida de qualquer pessoa em sociedade, o texto discute em linguagem acessível e clara esses impactos. Não sendo longo, acreditase poder ser lido e compreendido em cerca de 15 minutos, o que o torna adequado a uma aula. A abordagem simples também pode contribuir para uma leitura dinâmica e agradável.

\subsection{Conjuntos numéricos}

A história dos números surgiu da necessidade de contar e guardar os registros. Mas como as pessoas descobriram que a origem dos números, por consequência a matemática, aconteceu dessa forma? A Arqueologia é a ciência que se ocupa da investigação da presença humana através de vestígios materiais antigos, a fim de compreender o desenvolvimento da humanidade em determinado tempo e espaço. Os arqueólogos buscam e analisam utensílios muito antigos, os vestígios arqueológicos, nos quais há indícios de que os objetos ou marcações sobre eles signifiquem uma parte da história da humanidade. A localidade onde são encontrados vestígios arqueológicos é o lugar onde houve alguma ocupação humana, denominada sítio arqueológico. Métodos científicos modernos são muito utilizados na arqueologia, principalmente no que se refere à datação de vestígios arqueológicos. Através dos métodos Carbono-14 e a termoluminescência é possível descobrir com precisão idade de vestígios arqueológicos; esses métodos são baseados nas alterações químicas e físicas que acontecem lentamente ao longo do tempo com o material de que é constituído o objeto de estudo. 
A história dos números está ligada com a história dos registros das civilizações, pois esses registros são as únicas formas de comprovar as circunstâncias em que ocorreram a origem dos números. Visto que a linguagem oral não podia ser registrada.

Não há indícios de que os povos da antiguidade pré-histórica faziam uso de números racionais, o motivo pode ser pela arbitrariedade da escolha de uma unidade de medida conveniente para mensurar o que desejasse e com isso eliminar a forma fracionada de uma determinada grandeza.

Os documentos históricos escritos há seis milênios mostram que os símbolos usados no sistema de numeração eram agrupados, talvez para otimizar espaço e tempo com as marcações. $\mathrm{Na}$ sociedade antiga egípcia foi encontrado um sistema de numeração bem definido que agrupa dez símbolos que representa uma unidade, formando uma dezena e a cada dezena forma uma centena, assim por diante até o número um milhão. Os chineses também usavam a multiplicação para agrupar símbolos que representavam números.

Os algoritmos de adição, subtração, multiplicação estavam presentes nos sistemas de contagem e documentados em papiros. São conhecidas extensas tábuas de multiplicação de civilizações antigas. Eles sabiam que nem sempre uma certa medida resultava números inteiros, e com isso faziam uso da fração para representar divisões não exatas. É curiosa a forma de simbolizar frações encontradas no papiro Rhind (também conhecido como papiro Ahmes, escrito no Egito por volta de 1650 a.C. O papiro foi adquirido pelo escocês Henry Rhind e copiado pelo escriba Ahmes), qualquer fração era escrita como uma soma de duas ou mais frações sempre com o numerador sendo o número 1. O resultado dos problemas encontrados no papiro Rhind está correto, mas devido ao fato de restringirem os numeradores trazem complicações no desenrolar da resolução. Os antigos egípcios provavelmente sabiam que não era possível construir um quadrado de área igual a dois, mas eles usavam as tábuas de multiplicação onde tinham o resultado do produto de um número por ele mesmo, ou seja, eles construíram tábuas dos quadrados dos números e não necessariamente inteiros. Usaram a tábua que mostrava os números ao quadrado de forma inversa, dando origem a raiz quadrada. É fato que na resolução de problemas em que era inevitável a utilização da raiz quadrada, era proposto de forma que o cálculo resultaria em uma raiz exata. Quando não era possivel, eles achavam uma aproximação e davam-se por satisfeitos com o resultado.

Os indianos e chineses documentaram técnicas para calcular a raiz quadrada de um número aproximando-as das frações. Os babilônios também tinham tabelas de raízes quadradas e cúbicas, empregavam números racionais para atribuir o resultado aproximado de uma raiz não exata.

A gênese dos números irracionais é creditada, por muitos autores, aos pitagóricos. Muitas referências apontam Pitágoras como um dos maiores matemáticos 
da Grécia, devido ao grande volume de conhecimento produzido na escola que criou. Não só conhecimentos no campo da matemática foram desenvolvidos, mas também na ciência, filosofia, religião e política. A escola pitagórica, instituída por Pitágoras, localizada em uma colônia grega no sul da Itália, agregava pessoas unidas por ritos secretos. Na época as pessoas tinham o costume de atribuir seus feitos aos seus mestres, então provavelmente muitas descobertas creditadas a Pitágoras foram produzidas pelos seus alunos, chamados de Pitagóricos. A Escola pitagórica teve fim com um incêndio provocado por forças democráticas que não aceitavam a restrição do conhecimento produzido na escola imputado por Pitágoras às pessoas que não faziam parte da sua reservadíssima comunidade. Quase tudo foi incinerado, uma pequena parte que restou pode ser estudada por seus sucessores. Talvez muitos conhecimentos matemáticos, perdidos no incêndio, produzidos pelos pitagóricos não fazem parte da nossa realidade. Muitos alunos morreram na ocasião do incêndio, mas Pitágoras conseguiu fugir para outra parte da Itália e lá viveu até aproximadamente 80 anos de idade.

A escola pitagórica possuía como filosofia que os números inteiros e positivos eram a essência de todas as coisas, ou seja, tudo poderia ser ordenado e contado inclusive fenômenos físicos.

Na ocasião da frustração em perceber que a medida da diagonal de um quadrado não poderia ser dada por um quociente de números inteiros, levou a uma grande perturbação no desenvolvimento da matemática.

Assumindo o fato de que tudo poderia ser contado, os pitagóricos consideraram que existia uma unidade de medida capaz de relacionar a medida do lado de um quadrado com sua diagonal, ou seja, múltiplos de inteiros. Infelizmente os pitagóricos tiveram que desistir de sua filosofia básica de que tudo poderia ser explicado ou representado através de números e assumiram a existência de números incomensuráveis, isto é, números que não representa um valor múltiplo de unidades inteiras. Eles usaram argumentos lógicos para alegar a existência desse tipo de número, não necessariamente uma prova.

A matemática avançou bastante após a descoberta dos números incomensuráveis, que posteriormente foram chamados de números irracionais.

Percebe-se que as civilizações antigas como a egípcia e a babilônica tinham conhecimento e domínio dos números naturais e os racionais positivos, principalmente para resolver problemas práticos de contagem e mensuração de terras e tempo. Não há informações de que tais civilizações antigas fizessem uso de números negativos.

A utilização de números negativos e irracionais não aconteceu de forma a resolver problemas aplicáveis a vida cotidiana, mas sim para resolver problemas da própria matemática: manipulações algébricas.

Em livros chineses datados aproximadamente 200 a.C. tem-se problemas de equações lineares nos quais são usados números negativos como manobra algébrica 
para chegar às resoluções; essa é a primeira evidência amplamente conhecida sobre os primórdios uso de números negativos.

Desde então, os matemáticos passaram a usar os números negativos de forma indiscriminada. Os números negativos eram considerados essenciais para resolver problemas algébricos. Seu significado era apoiado em fenômenos físicos, mas não havia uma fundamentação matemática apropriada. Os matemáticos Francis Maseres (1731-1824) e William Frend (1757-1841) elaboraram um texto de álgebra, no qual rejeitaram a utilização de números negativos. Certamente foi uma medida drástica e desproporcional para tratar de um assunto amplamente aceito.

Para resolver o problema da obscuridade dos números negativos, o inglês George Peacock (1791 - 1858) em sua notável obra Treatise on Algebra com intenção de fazer a reforma na matemática que incluiu a formalização do significado dos números negativos propondo que a álgebra seja segmentada em duas partes. Uma parte é um meio de desenvolver os princípios básicos da aritmética dos números reais e não negativos utilizando incógnitas. A outra parte deriva da aritmética, cálculos com incógnitas, não é restrita aos números negativos nem é necessária uma aplicabilidade. Peacock definiu número negativo como uma sendo um símbolo da forma - a, as operações $e$ propriedades.

A comunidade matemática aceitou fortemente os números negativos quando o irlandês William Rowan Hamilton (1805 - 1865) relacionou o sinal do número ao sentido do número através da reta numérica (análogo a vetores). Por exemplo, o produto de dois números negativos resulta em um número positivo, visto que esse produto acarreta na inversão do sentido duas vezes. Muitas descobertas no ramo da física estavam bloqueadas devida a falta da formalização, operações e propriedades dos números negativos comuns a todos no campo da ciência. Apoiado na argumentação de Hamilton, foi criado um tratado que continha equivalente a quase todas as leis modernas de produto vetorial e escalar de vetores, essenciais para o estudo da cinemática.

$O$ conjunto dos números racionais e o conjunto dos números irracionais são, por definição, conjuntos disjuntos. Vários matemáticos do século XX estudaram uma maneira de compor um grupo no qual os dois conjuntos fizessem parte. A teoria que mostrou ser bem argumentada e sem falhas aparentes em sua demonstração foi elaborada por Richard Dedekind (1831-1916). Ele foi responsável pela criação dos números reais estabelecendo uma correspondência biunívoca entre os pontos de uma reta e os números reais.

Todo o estudo sobre os números e conjuntos que são tratados no Ensino Médio recebeu um trabalho bem abrangente e completo do matemático Georg Cantor com a teoria dos conjuntos infinitos, a qual permitiu resolver problemas considerados insolúveis ao longo do tempo. Já os conjuntos numéricos receberam uma teoria generalizada desenvolvida pelo matemático Paul Halmos (1916 - 2006), intitulada "Teoria 
Ingênua dos Conjuntos".

\section{Considerações sobre o tema}

Usualmente, os livros didáticos de nível fundamental introduzem o conceito de números negativos associando-o a temperaturas e cálculos de débito x crédito. A construção do conhecimento através dos temas abordados na introdução tem relevância, porém ela se perde no momento em que é apresentada as formas de operar esses números. O aluno do Ensino Médio provavelmente já aprendeu operar estes tipos de números, mas como supostamente as operações de multiplicação e divisão não têm significado e são resumidas a "jogos de sinais" a tendência é que o aluno estenda a regra para as outras operações (adição e subtração).

Sugestão de atividade: usar a história da evolução dos conjuntos numéricos, enfatizando os questionamentos causados nos matemáticos da época a fim de construir o conceito lógico e significativo.

Os números negativos têm sua história atrelada aos números imaginários. Para o primeiro ano do Ensino Médio, o conteúdo programático é limitado ao conjunto dos números reais, desta forma, no texto não há alusão aos números complexos, que é programado para o terceiro ano do Ensino Médio. O conjunto dos números complexos, nesta etapa do ensino, pode ser citado como um teor curioso: conjunto numérico que contém o conjunto dos números reais.

\subsection{Função}

$\mathrm{Na}$ sociedade humana sempre houve relações de dependência. As crianças dependem dos adultos para sobreviverem no início da vida, dependemos do padeiro para termos o pão diariamente, do despertador para não perdermos a hora, do veículo para nos levar ao nosso local de trabalho distante de casa... O que pagamos pela alimentação também depende do que compramos, por exemplo: um abacaxi, quatro reais, dois abacaxis, oito reais, e assim por diante. E o que isso tem a ver com funções

Ora, função também tem o conceito atual de relação de dependência! Assim, o que você paga é função do que você consome, a quantidade de combustível que um carro consome é função da distância que ele percorre e da velocidade que desenvolve, o preço da conta de luz de sua casa é função da quantidade de quilowatts (kw) que sua família consome, e assim por diante! Esse conceito vale hoje, na sociedade contemporânea, mas ao longo do tempo teve algumas modificações.

A necessidade de os homens criarem meios de relacionarem fenômenos naturais fez com que a ideia de função surgisse nos primórdios da humanidade, que sempre buscou maneiras de entender como a natureza se comporta por meio da observação 
de fatores naturais. O homem como um ser pensante e diferente dos outros animais não está satisfeito em suprir suas necessidades básicas e busca sempre uma forma de interferir em certos momentos para que aumente o bem-estar de si próprio e de sua comunidade.

Não se tem ao certo de como foi a criação do conceito de função, mas sabe-se que veio da observação de duas grandezas que se relacionam através de uma propriedade. O indício mais antigo da utilização de funções data de 2000 a.C, acreditase que egípcios já utilizavam a ideia de funcionalidade para resolver problemas, e os gregos escreviam tabelas que associavam a matemática com a astronomia.

O nome "função" foi usado pela primeira vez pelo alemão Leibniz, um matemático, filósofo, cientista, diplomata e bibliotecário que viveu de 1646 a 1716. O referido termo servia para se referir a retas que se relacionam com curvas. Ele também introduziu os termos "constantes", "variáveis" e "parâmetros".

A forma da função dada por " $f(x)$ " foi dada pelo suiço Jacob Bernoulli, na mesma época em que Leibiniz estudava a função. Ao que parece, esses dois matemáticos trocavam informações constantemente sobre o assunto. Antes disso Newton usava a palavra "fluente" para dar o mesmo sentido de função que Leibniz aplicava.

No século XVII filósofo matemático francês René Descartes (1596 - 1650) usou a letra " $y$ " como variável para indicar a dependência com a letra " $x$ " através de uma lei de formação. Descartes introduziu curvas em um plano bidimensional de eixos perpendiculares através de uma equação que associava a variável " $x$ " com a variável "y".

Descartes também criou o cartesianismo, que é uma doutrina caracterizada pelo racionalismo, pela consideração do problema do método como garantia da obtenção da verdade, e pelo dualismo metafísico. O nome do plano de dois eixos perpendiculares usado para plotar curvas oriundas de uma lei de formação é chamado de Plano Cartesiano porque Descartes adotava o pseudônimo Cartesius.

O cartesianismo usava a matemática para explicar a filosofia através de leis e fenômenos físicos descobertos por vários matemáticos, físicos e filósofos da época.

Após a criação e divulgação do conceito de função criada por Descartes, juntamente com o plano cartesiano e as coordenadas $(x, y)$, esse assunto matemático tornou-se estudado por grandes matemáticos de diversas partes do mundo o que gerou uma grande variedade de notações e definições acerca do tema.

A definição atual de função deve-se ao grupo de matemáticos chamado de Bourbaki. No período que antecede a segunda guerra mundial este grupo foi formado na França com o intuito de produzir um material no qual tivesse absoluto rigor matemático em temas de várias áreas como: álgebra, cálculo diferencial e integral, topologia e funções. A elaboração dos seis volumes terminou no pós-guerra com o elenco do Bourbaki renovado e a definição (e notação) utilizada atualmente, transcrita a seguir, 
e encontrada em qualquer livro de matemática.

"Sejam $X$ e $Y$ dois conjuntos quaisquer. Uma função é uma relação $f$ : $X \rightarrow Y$ que, a cada elemento $x \in X$, associa um e somente um elemento $y \in Y$ ".

Nos dias de hoje, a "função" se aplica muito bem em diversas áreas do conhecimento, dando tratamento matemático para a ecologia, biologia, economia, física, transformando fenômenos naturais e sociais em equações algébricas com significado real de suas variáveis em relação de dependência. Através da análise de uma situaçãoproblema transformada em função podemos observar o comportamento de tal curva estimando posturas futuras.

\section{Considerações sobre o tema}

O conceito de função como é observado nos livros atuais para alunos do Ensino Médio da Secretaria do Estado de Educação do Distrito Federal nem sempre foi apresentado da maneira que é hoje. Existe uma longa trajetória, durante anos, em que estudiosos contribuíram para o conceito tornar-se o que é nos dias presentes.

Mais uma vez, pode se constatar que o texto é curto, simples, objetivo e de fácil compreensão, fluido e aborda situações bem presentes na realidade dos alunos. Isto pode vir a tornar o texto motivador e integrável a uma aula onde se introduz o conceito de função.

Sugestão de atividade: o texto pode ser distribuído pelo professor no início da aula para ser lido pelos alunos em cerca de dez minutos. Uma vez que a ideia de função foi vista no nono ano do Ensino Fundamental, o professor pode solicitar dos alunos, em seguida, que identifiquem no texto lido situações do cotidiano onde ocorre relação de dependência. Após isso, a turma pode ser inquirida sobre outras situações no próprio cotidiano onde se observa alguma relação de dependência. O momento seguinte será a exposição do tema.

As situações apresentadas poderão servir de ideias para a elaboração de exemplos com os quais o professor ilustrará o assunto. Assim, o texto fica adequadamente relacionado com a aula.

\subsection{Geometria plana}

A observação do meio em que viviam, fez civilizações antigas estudarem a geometria plana de forma prática como a noção de distância, principalmente. A preocupação de medir o tamanho de um determinado terreno foi o marco inicial para que os antigos egípcios tivessem noção de figuras simples como o quadrado, retângulo e o triângulo. Há indícios que as antigas civilizações sabiam calcular a área do retângulo e do triângulo usando o produto das medidas da base pela altura e a metade do pro- 
duto entre as medidas da base e da altura respectivamente. Nem sempre os territórios possuíam dimensões perpendiculares, situação que dificultava o cálculo da área. Para resolver este problema, usavam-se aproximações das medidas, fato que deixou os escribas satisfeitos por um tempo.

A prática de aproximar medidas com a finalidade de tornar os cálculos descomplicados era muito comum. Em papiros babilônicas, o perímetro da circunferência é expresso pelo triplo do diâmetro. Outras escrituras também remetiam ao comprimento da circunferência como sendo três vezes o diâmetro, como por exemplo, o antigo livro chinês Jiuzhang e na Bíblia hebraica.

O grande contratempo era maneira de calcular a área da circunferência. Algumas formas de calcular a área da circunferência foram identificadas no papiro Rhind (ou Ahmes). Este papiro, datado de 1650 a.C., é um texto matemático egípcio que contém 85 problemas com resoluções. Nesse papiro, a área da circunferência resulta no quadrado de 8/9 do diâmetro. A constante que hoje é conhecida como $\pi$ (pi) se resumia a 256/81, ou seja, dízima periódica $3,160493827 \cdots$ que é um resultado excelente.

Outra maneira de calcular a área da circunferência encontrada nesse mesmo papiro é aproximar a área da circunferência da área de um octógono, ambos inscritos em um mesmo quadrado. Os babilônios e os chineses abordaram de modo distinto o problema de área. Eles usavam a fórmula $A=(C / 2)(d / 2)$ para calcular a área da circunferência. Acredita-se que eles tenham chegado a essa fórmula dividindo a circunferência em setores circulares e organizando-os numa figura próxima a de um retângulo.

A geometria plana também é conhecida como geometria euclidiana em virtude de uma obra essencial para o estudo do tema, intitulada "Os Elementos", cujo autor é conhecido como Euclides de Alexandria (desconhece-se o local e data de nascimento). A obra foi escrita há mais de 2300 anos, também em um papiro, foi fundamental para a formalização de conceitos, definições, axiomas, postulados, teoremas e corolários de geometria. A referida obra, Os Elementos, é composta por treze livros ou capítulos que tratam da matemática elementar no campo de teoria dos números, álgebra e geometria espacial. Em sua grande parte, versa sobre a geometria plana. Esta obra foi traduzida em inúmeras línguas, com mais de mil edições e só não mais impressa que a bíblia.

A biografia do autor de Os Elementos é escassa. Não se tem um consenso sobre qual é o sobrenome de Euclides. Ele é conhecido como Euclides de Alexandria por ter passado uma parte de sua vida dedicada às pesquisas e ao ensino de matemática no museu (templo das musas) situado em Alexandria no Egito. O museu, local onde os intelectuais se reuniam para produzir e propagar conhecimento, é comparado com a universidade da atualidade. Várias pesquisas na literatura precedente, efetuadas por 


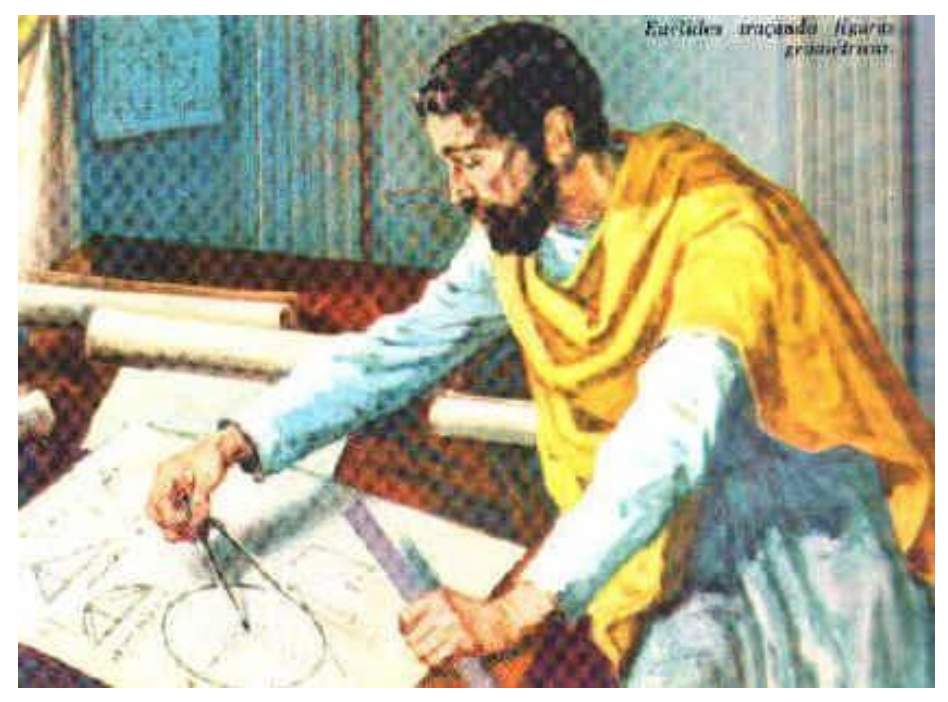

Figura 3.1: Euclides.

(fonte: Só matemática). Disponível em:

<http://www.somatematica. com.br/biograf/euclides.php> Acesso em: set. 2016.

Euclides nesta época áurea, foram possíveis porque o Rei Ptolomeu I financiava os museus, os intelectuais a captura dos papiros de forma não muito amigável de cidades dominadas pelo seu reino. Foi criado um enorme acervo de papiros nesta época.

Euclides de Alexandria criou várias obras notáveis, mas se consagrou com Os Elementos. Esta produção não foi de completa criação de Euclides, pelo contrário, ele organizou conceitos e demonstrações já existentes e elaborou o livro de forma lógica, objetiva e completa com os elementos da matemática em especial a geometria. Outros materiais com o mesmo objetivo de Os Elementos existiram, mas caíram no esquecimento pois, Os Elementos era pleno. A matemática moderna tornou-se sofisticada e os matemáticos bem mais críticos quanto ao rigor e lógica empregada nos documentos científicos. Fato que alguns matemáticos assumem a importância de Os Elementos, mas percebem falha quanto á lógica primitiva empregada às primeiras definições de conceitos.

Embora Os Elementos tenham uma apreciação pouco didática para leitores modernos devido à falta de exemplos, comentários e cálculos, é uma amostra de "matemática pura" muito estudada. As biografias de muitos matemáticos indicam que a obra de Euclides lhes forneceu a sua primeira abordagem matemática, que ela de fato entusiasmou e motivou para tornarem matemáticos.

A geometria plana, vista basicamente no Ensino Fundamental, tem conteúdos que ainda vão servir de base para estudos no Ensino Médio. Por exemplo, o que foi visto sobre relações métricas no triângulo retângulo, seno, cosseno e tangente de seus ângulos agudos, vai fundamentar o estudo da trigonometria especificamente as funções no círculo trigonométrico unitário, e depois as relações inversas, ou seja, cossecante, secante e cotangente respectivamente. 
Algumas outras aplicações de conteúdos da geometria plana também serão utilizadas na construção de outros conteúdos do Ensino Médio, principalmente geometria espacial. Uma vez que as faces dos sólidos geométricos, chamados poliedros, constituem-se de figuras geométricas planas - triângulos, quadrados, pentágonos, etc. conteúdos desta área da matemática vão fundamentar os da geometria espacial.

\section{Considerações sobre o tema}

O texto é válido no sentido de ser uma base fundamental para o desenvolvimento de outros conteúdos do Ensino Médio, como ele próprio sinaliza nos seus parágrafos finais. Isto o torna útil e possivelmente motivador para os alunos, pois é nesse nível de ensino que estão. Além disso, sendo mostrado no texto de forma leve e objetiva, poderá permitir ao aluno associar conhecimentos anteriores adquiridos por ele, portanto situações já enfrentadas com novas situações que se farão presentes ao longo de seus estudos.

Conforme visto no tópico 2.3, a matriz curricular para o Ensino Médio no Distrito Federal contém, em seus conteúdos, uma revisão de geometria plana. Assim sendo, considera-se que este é momento mais propício para utilizar o texto.

Sugestão de atividade: no início da revisão sobre geometria plana, o professor pode utilizar o texto, o qual poderá servir de elemento motivador para o estudo. Após a leitura feita em aproximadamente quinze minutos, o professor pode apresentar a demonstração da área da circunferência conforme foi abordada pelos babilônicos e chineses, incluindo os esboços gráficos que poderão ser mostrados no quadro. O professor ainda pode levar os alunos a uma reflexão e discussão sobre a relevância da obra "Os Elementos" no desenvolvimento da matemática e também a utilização de seus conteúdos no ensino de matemática atual. É nesse momento que o professor pode reforçar quais outros conteúdos de matemática a serem vistos por seus alunos serão compreendidos a partir dos diversos tópicos desta obra.

\subsection{Matrizes e Sistemas lineares}

As informações organizadas em tabelas aparecem frequentemente nos meios de comunicação, como por exemplo em jornais, revistas e sites. Essas tabelas podem ser interpretadas usando conhecimentos de matrizes que se aprende na escola.

Um exemplo muito interessante é a tabela que mostra a classificação dos times que disputam o campeonato brasileiro da série A. Esta tabela é formada por várias matrizes justapostas que se relacionam umas com as outras.

Na primeira coluna aparece a quantidade de pontos em ordem decrescente que cada time possui. Para definir a pontuação é realizada uma multiplicação de ma- 
trizes. A matriz coluna que contém a pontuação é o resultado da multiplicação entre a matriz que compreende a quantidade de vitórias, empates e derrotas e a matriz coluna formada pela quantidade de pontos que vale uma vitória (3 pontos), um empate (1 ponto) e uma derrota (0 pontos).

A tabela também apresenta o saldo de gols dos times, que novamente pode ser calculado usando as operações com matrizes, mas neste caso é a subtração da matriz coluna que representa a quantidade de gols pró pela quantidade de gols contramarcados pelos times. A tabela de classificação finaliza com o percentual de aproveitamento dos clubes.

A seguir, é apresentada a figura de uma tabela que expressa os dados referentes aos jogos de um campeonato de futebol intitulado "Brasileirão série A". Este campeonato é realizado anualmente e a figura da tabela refere-se aos resultados obtidos até a data de 14 de agosto de 2016.

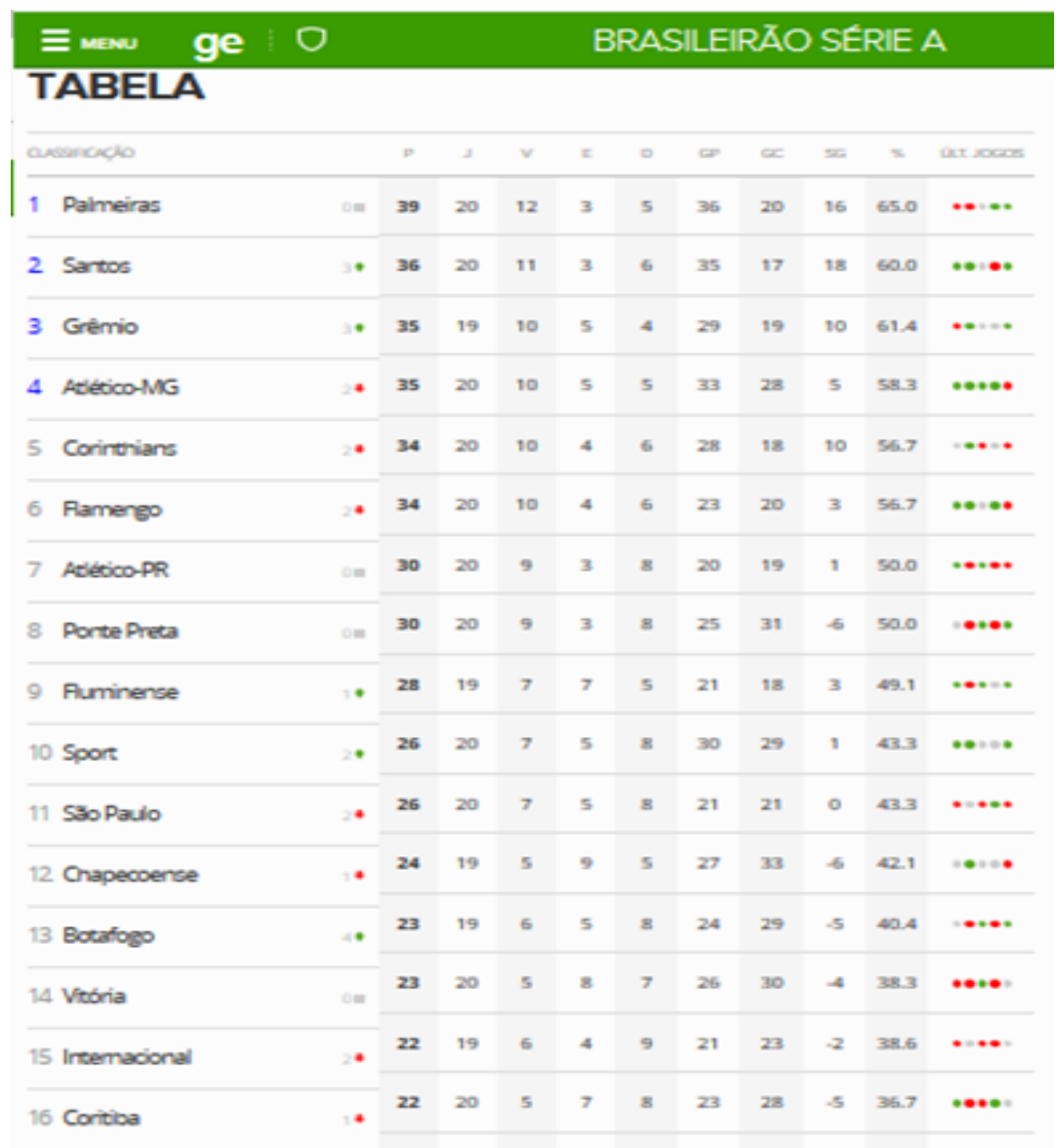

Figura 3.2: Tabela do Campeonato Brasileiro - Séria A (fonte: Globo Esporte). Disponível em:

<http://globoesporte.globo.com/futebol/brasileirao-serie-a/> acesso em: ago. 2016. 
A evolução dos conceitos, operações de matrizes e sistemas lineares acontece na ordem inversa da qual é estudada no Ensino Médio, pois os antigos babilônios, primeiro, preocupavam-se em resolver os problemas cotidianos que impactavam em suas vidas diretamente. Posteriormente outras gerações, provavelmente, em outros lugares estudavam a solução com profundidade, observando se tal método era aplicável a outros problemas formando uma generalização. Por consequência, houve necessidade de criar símbolos para que o entendimento fosse melhor organizado e compreendido, prosseguindo na evolução do conhecimento, procurando novas maneira de resolver aqueles e novos problemas através de propriedade que seriam provadas.

A cronologia da evolução das matrizes data por volta do ano 300 a.C., quando os babilônios registraram, em tabletes de argila, problemas que envolviam sistema de equações lineares. Um dos dilemas encontrados consistia em calcular o tamanho de dois campos, cuja soma de suas áreas, taxa de produção de cada campo e produção total de cereais eram conhecidos.

Pelo que é sabido pelos pesquisadores, esse problema babilônio não tinha nenhuma relação com matrizes. A relação de sistema lineares com matrizes foi observada em um livro chinês chamado "Nove capítulos da arte matemática" que data o século II a.C., no qual apareciam vinte problemas no estilo da questão exposta anteriormente. O que chamou bastante atenção nesta obra é o caso de um dos problemas ter uma resolução que organizava os coeficientes em uma tabela, o que remetia à ideia de matriz. Os chineses representavam os sistemas lineares por meio de seus coeficientes escritos com barras de bambu sobre os quadros de um tabuleiro, o método que conhecemos hoje como "Eliminação de Gauss".

Carl Friedrich Gauss (177ry - 1865), sem dúvida, foi uma das mentes mais brilhantes conhecidas pela humanidade. Ele nasceu na Alemanha de uma família humilde. Seu pai trabalhava como mestre de obras e não considerava os estudos tão importantes. Sua mãe, embora não tivesse sido letrada, foi a responsável por apoiá-lo e providenciar a matrícula na escola pública.

A notável inteligência de Gauss chegou ao conhecimento de um duque que decidiu investir em seus estudos. Aos 18 anos Gauss ingressou na Universidade, seus estudos baseavam-se principalmente nos campos de matemática, física e astronomia. Neste ano Gauss já era responsável por criar um método que possibilitou calcular a órbita de um asteroide recém-descoberto escondido atrás do Sol. Em outra época, o asteroide apareceu em plenitude e verificou-se que os cálculos de Gauss estavam corretos.

O método que Gauss usou para calcular a órbita do asteroide é conhecido como "mínimos quadrados", segundo o qual uma das etapas do desenvolvimento do método é calcular um sistema de equações lineares com várias incógnitas. Gauss organizou e combinou as equações com objetivo de reduzir as incógnitas. Ele conseguiu chegar à solução, mas o processo não era muito didático. Os registros mostram que 
Gauss resolveu o sistema usando essa técnica que é bem parecida com a que recebe o nome dele, atualmente. O geodesista alemão Wilhelm Jordan (1842 - 1899) foi o responsável por simplificar o método criado por Gauss: omitindo as incógnitas e formando uma matriz triangular com os coeficientes baseadas na manipulação algébrica das equações.

Os livros descrevem esse mesmo método em diferentes denominações: Eliminação de Gauss, Escalonamento (matriz triangular se assemelha a uma escada), Gauss-Jordan; todos se referem ao mesmo método. A importância deste está no fato de poder encontrar diretamente o valor das incógnitas de qualquer sistema de equações lineares, com soluções possíveis.

O termo "matriz" foi visto na literatura matemática pela primeira vez em 1850, através do inglês James Joseph Sylvester (1814 - 1897), que usou esse vocábulo para nomear um conjunto de números em forma de tabela. A teoria formal tendo as matrizes como protagonistas, veio da dedicação no estudo do tema do inglês Athur Cayley (1821 - 1895), amigo de profissão de Sylvester, ambos advogados que dedicavam a matemática nas horas vagas. Carley foi o primeiro a fazer um artigo que desvinculava as matrizes dos determinantes. Intitulado de "Memoir on the Theory of Matrices", 1858, o trabalho de Carley é dedicado a demonstrar a utilidade, definição, notação, propriedades e operações com matrizes, como está iniciado hoje este assunto no Ensino Médio.

\section{Considerações sobre o tema}

Os estudos de matrizes começaram na ordem inversa da qual se observa em livros didáticos. Nos materiais escolares, que se têm hoje, estudam-se primeiramente matrizes com conceitos, propriedades e operações; após tem-se o ensinamento sobre determinante, e por último, sistemas de equações lineares com vários métodos de resolução. Nas Orientações Curriculares para o Ensino Médio instrui que o estudo sobre determinante deve ser abandonado, pois ele "apenas" tem utilidade na resolução de sistema de equações lineares pelo método de Cramer, que por sua vez também deve ser dispensado por ser muito limitado e com pouco significado. O método proposto pelas Orientações Curriculares é o processo de escalonamento, com discussão acerca dos sistemas de solução única, com infinitas soluções e sem solução.

Sugestão de atividade: a leitura do texto pode acontecer na aula introdutória do tema, o que levará cerca de 20 minutos. Usando a tabela do campeonato brasileiro, o professor pode propor aos alunos que eles verifiquem a seguinte afirmação: considerando dois times com a mesma pontuação e números de jogos, sempre o time que ganhou mais partidas também perdeu mais partidas. O professor deve associar a atividade com a ideia de matriz. O problema babilônico comentado no texto também 
pode servir de exemplo contextualizado: Existem dois campos cuja área total é de 1.800 jardas quadradas. Há em um dos campos a produção de grãos, à taxa de $2 / 3$ de alqueire por jarda quadrada, enquanto no outro campo se produz o grão a uma taxa de $1 / 2$ de alqueire por jarda quadrada. Se o rendimento total é de 1100 alqueires, qual é o tamanho de cada campo? Alqueire era uma unidade de capacidade que representava a produção de cereais, normalmente aparecia vinculada ao volume sobre uma certa área (taxa).

\subsection{Sequências e Progressões}

Um garoto americano de apenas 13 anos de idade, chamado Aidan Dwyer, em 2011, observou que comportamento dos galhos de várias árvores da sua cidade não era somente um emaranhado de galhos desordenados, mas obedeciam uma sequência. Em 1954 o naturalista Charles Bonnet já havia comprovado que o comportamento de algumas plantas obedecia uma ordem, conhecida como sequência de Fibonacci. Aidan fez fotografias de diferentes árvores. Após isso, escolheu a árvore de carvalho para ser seu objeto de estudo, com um experimento no qual usou transferidor, bússola e recursos computacionais. Concluiu que a disposição dos galhos obedecia a sequência de Fibonacci.

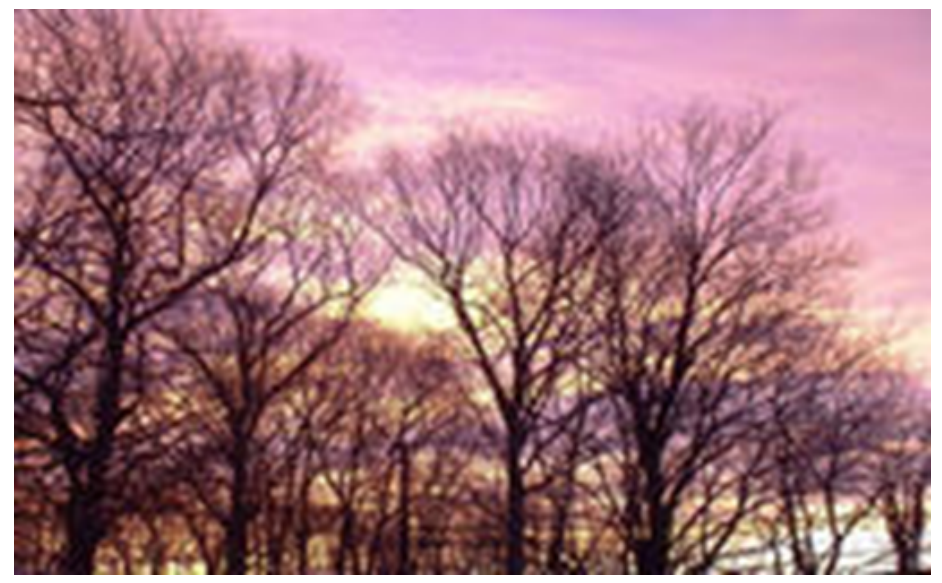

Figura 3.3: Árvores de carvalho (fonte: Amnh). Disponível em:

http://www.amnh.org/learn-teach/young-naturalist-awards/winning-essays2/2011winning-essays/the-secret-of-the-fibonacci-sequence-in-trees/. Acesso em: jul. 2016. 


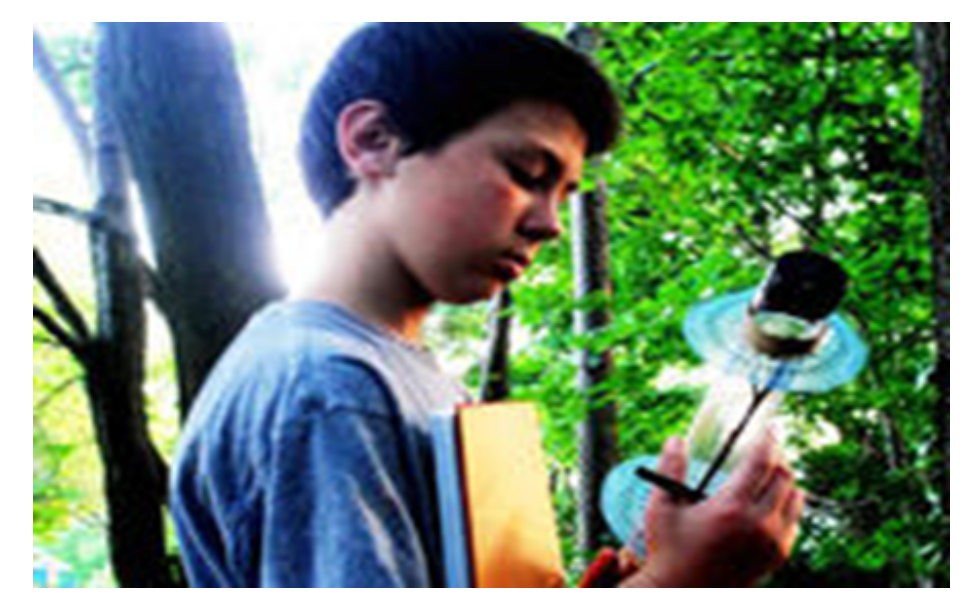

Figura 3.4: Aidan estudando a disposição dos galhos (fonte: Amnh). Disponível em:

http://www.amnh.org/learn-teach/young-naturalist-awards/winning-essays2/2011winning-essays/the-secret-of-the-fibonacci-sequence-in-trees/. Acesso em: jul. 2016.

Aidan acreditava também que a fotossintese estava diretamente relacionada com a disposição dos galhos e consequentemente das folhas. Para provar sua teoria, ele construiu dois projetos que geram energia através da captação da luz solar. O primeiro projeto ele dispôs as placas dispostas análogas aos galhos observados na árvore de carvalho e o chamou de árvore de Fibonacci. No segundo projeto ele arrumou a mesma quantidade de placas no padrão comum produzidas por empresas que instalam equipamentos geradores de energia solar. Observou que o rendimento da árvore de Fibonacci superou de $20 \%$ a $50 \%$ as placas organizadas no modelo padrão, dependendo da época do ano.

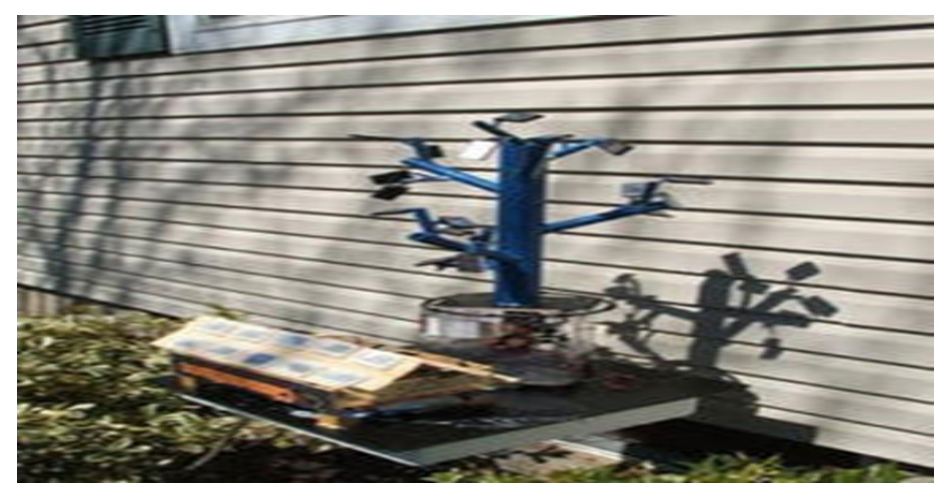

Figura 3.5: Os dois projetos de coleta de luz (fonte: Amnh). Disponível em:

<ttp://www.amnh.org/learn-teach/young-naturalist-awards/winning-essays2/2011winning-essays/the-secret-of-the-fibonacci-sequence-in-trees/>. Acesso em: jul. 2016. 


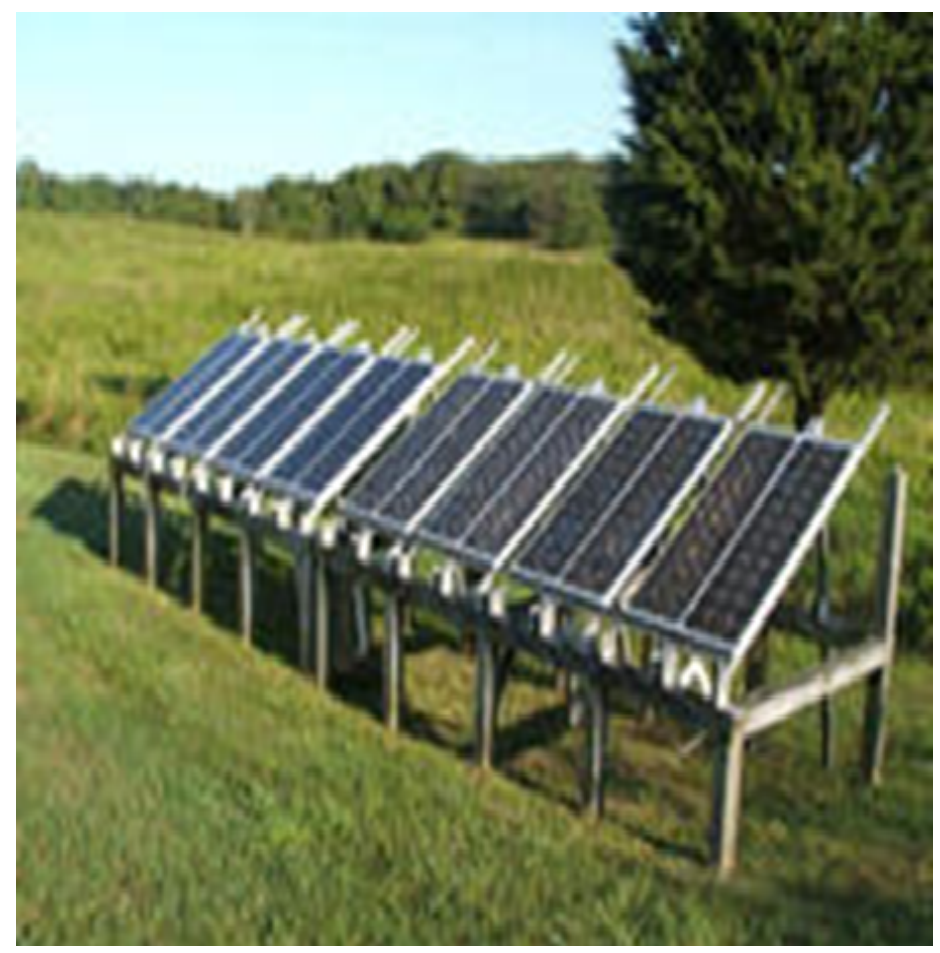

Figura 3.6: Modelo típico de captação de luz solar (fonte: Amnh). Disponível em:

$<$ http://www.amnh.org/learn-teach/young-naturalist-awards/winning-essays2/2011winning-essays/the-secret-of-the-fibonacci-sequence-in-trees/>. Acesso em: jul. 2016.

Os fenômenos da natureza apresentam regularidades que constituem objeto de estudo da matemática. Através de determinados padrões observados pela humanidade é possivel prever ocorrências. Foi nesse sentido que povos antigos tiveram interesse por sequencias e progressões. Há mais de 4 mil anos, os babilônios, por exemplo, preocupavam-se com a frequência da cheia do rio Eufrates porque impactava diretamente na dinâmica da comunidade que dependia de certeza do momento da enchente do rio para as plantações serem bem sucedidas.

As sequências e progressões despertaram interesse de muitas mentes brilhantes e localidades de tempo e espaço distintos. Para mostrar a evolução do conhecimento a respeito do tema, faz-se uma sucessão cronológica enfatizando o local geográfico no qual a ideia foi concebida e o percussor.

$\mathrm{Na}$ Mesopotâmia e no Egito foram encontrados os tabletes, ou tábuas de barro mole nas quais se faziam as escritas e depois eram cozidas, conhecidos como "Plimpton 322" e o papiro "Rhind" escritos entre 1900 a 1600 a.C. Neles são encontrados problemas que envolvem soma de números que estão em progressão geométrica. Por volta de 600 a.C., os membros da escola pitagórica estudaram sequencias de números que eram observadas na formação de figuras geométricas. Muitas pessoas acreditam que o texto matemático mais célebre de todos os tempos, "Os Elementos" de Euclides, 
trata apenas de geometria, apesar da maioria do trabalho ser destinado à ela, tem-se uma parte dedicada a teoria dos números e nela faz-se um tratamento de progressões.

Muitos outros importantes matemáticos se entusiasmaram com sequências como Diofanto de Alexandria (Grécia, 250 a.C.-166 a.C.) publicou em sua obra mais importante, Aritmética. O Matemático hindu mais significativo do século XII Bhaskara (1114-1185) em seu trabalho mais conhecido, "Lilavati". Em 1202. Michael Stifel (Alemanha, 1486-1567), maior algebrista alemão do séc. XVI. Em sua maior obra "Arithmetica integra", publicada em 1544.

Leonardo de Pisa (Itália, 1170-1250), conhecido como Leonardo Fibonacci por causa de uma adaptação do sobrenome de seu pai Guilielmo Bonacci, escreveu em seu livro denominado "Liber Abacci" uma das sequencias mais famosas da história: a sequência de Fibonacci. O problema é introduzido baseando-se em tratamento matemático de uma população de coelhos em ambiente ideal, no qual a reprodução acontece mensalmente, sempre com os coelhos em fase adulta gerando um par de coelhos por mês. Principia com um casal de coelhos filhotes que se tornam férteis na fase adulta um mês depois. No segundo mês o casal adulto gera um casal de coelhos, totalizando dois pares de coelhos. No terceiro mês o primeiro casal de adultos gera mais um casal de coelhos e seus descendentes tornam-se adultos. No mês seguinte os coelhos adultos geram mais um casal de coelhos e os filhotes tornam-se adultos e assim sucessivamente. A sequência de Fibonacci é formada pelos números que representam a quantidade total de pares de coelhos por mês: 1, 1, 2, 3, 5, 8, 13, 21,...

Nota-se que a solução desse problema gera uma sequência que é amplamente estudada com várias aplicações na natureza e recheada de inúmeras propriedades interessantes, incluindo a relação da sequência de Fibonacci com o número áureo.

O escocês John Napier, que viveu de 1550 a 1617, possuía um conhecimento exímio de progressões aritméticas e geométricas. Seu grande feito consiste na elaboração da correspondência entre as progressões, ideia que levou Napier a criar os logaritmos. Dentre outras funções, essa ferramenta ajuda a simplificar cálculos aritméticos e algébricos.

$\mathrm{Na}$ história da evolução dos estudos das progressões, o alemão de família humilde Carl Friedrich Gauss (17r7y - 1855) tem um papel importantíssimo acerca da soma da progressão aritmética. Aos 10 anos de idade em sua escola, Gauss respondeu quase que instantaneamente a tarefa que o seu professor havia proposto, que era calcular a soma de todos os números naturais de 1 a 100. Ele calculou mentalmente a soma da progressão aritmética $1+2+3+4+5+\cdots+100$, observando a soma dos pares de números extremos da sequência resultava em uma constante, ou seja, $100+1=101$, $99+2=101,98+3=101$ e assim por diante. Gauss formou 50 pares cuja soma dos números de cada par resultou 101. Então, ele concluiu que a soma de todos os números naturais de 1 a 100 é dada por $50 \times 101=5050$. Além de o professor generalizar o 
raciocínio de Gauss criando a fórmula que hoje é usada para somar termos de uma progressão aritmética, levou a genialidade do garoto ao conhecimento do príncipe duque da cidade, pessoa que custeou os estudos posteriores de Gauss.

A vida adulta de Gauss foi repleta de feitos relacionados as ciências exatas. É considerado o "Principe dos matemáticos", porque quando Gauss morreu, o rei de Hanover ordenou que se esculpisse uma medalha comemorativa em sua homenagem, escrita Georgius V. rex Hannoverge Mathematicorum principi (Jorge V rei de Hanover ao Principe dos Matemáticos).

Outros matemáticos, além de Gauss, Napier e Fibonacci deixaram estudos sobre interessantes sequências como legado para a matemática.

\section{Considerações sobre o tema}

Este texto pode ser interessante por causa da precocidade matemática revelada por Gauss, o que cativou, inclusive, a autora desta dissertação, ao tomar contato com a história através do seu professor de matemática, enquanto estudante do Ensino Médio.

A abordagem relativa a Aidan Dwyer também pode ser igualmente atraente, em vista de também enfocar a precocidade do adolescente, vivendo em época tão recente.

Vale lembrar que este tema é precursor do estudo dos logaritmos, também conteúdo do Ensino Médio.

Sugestão de atividade: o professor pode apresentar o texto para ser lido pelos alunos na aula introdutória de sequências e progressões, nos primeiros 15 minutos. Após a leitura do texto, o professor pode propor que os alunos, inspirados na ideia de Gauss, calculem algumas somas de sequências aritméticas dadas por ele, buscando algum padrão de resposta para qualquer quantidade de termos das sequências.

\subsection{Função Logarítmica}

Os terremotos são oriundos do choque entre placas tectônicas. Os registros dos abalos provocados por terremotos começaram em 1900 com a invenção do aparelho que mede a força dos tremores, o sismógrafo. Em 1935 Charles Richter e Beno Gutenberg desenvolveram a escala Richter, como o objetivo de medir a magnitude de um terremoto em graus, através do tamanho das ondas produzidas pela liberação de energia gerada pelo choque entre placas tectônicas. O grau na escala Richter é determinado pela função logarítmica $M=\log A-\log A_{0}$, onde $M=$ magnitude(grau), $A=$ amplitude máxima e $A_{0}=$ amplitude de referências. Não existe um valor máximo para a escala Richter, porém a maior magnitude registrada foi de 9,5 graus em 1960 no Chile. Este 
terremoto causou um maremoto com ondas gigantescas de 10 metros de altura, que cobriu cidades litorâneas chilenas e vitimou milhares de pessoas.

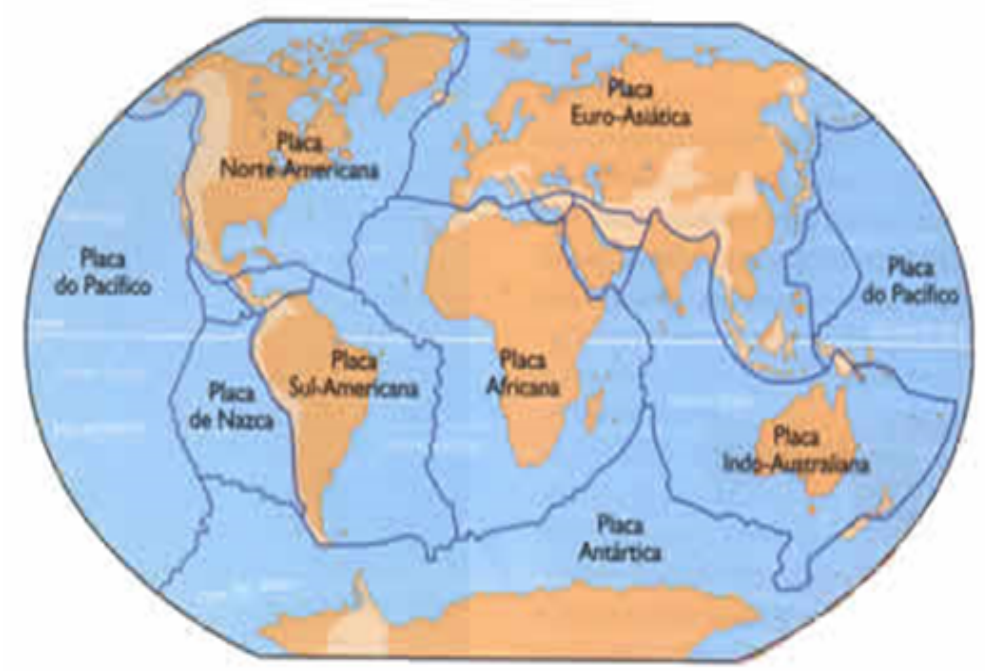

Figura 3.7: Placas Tectônicas

(Fonte: Uol Educação). Disponível em:

$<$ http://educacao.uol.com.br/disciplinas/geografia/circulo-de-fogo-do-pacifico-regiaoconcentra-as-ocorrencias-de-terremotos-e-atividades-vulcanicas.htm>.

Acesso em: abr. 2016.

Hoje, uma das principais aplicabilidades do logaritmo é para resolver problemas no qual a incógnita aparece no expoente de uma potência dentro de uma equação. Ao aplicar o logaritmo em uma equação exponencial, tem-se toda a equação transformada em uma polinomial. O cálculo torna-se mais simples.

O contexto histórico atribuído à criação do logaritmo está intimamente ligado aos problemas cotidianos da época, que eram resolvidos de maneira extensa e exaustiva, porque faltavam ferramentas matemática que possibilitava a simplificação dos cálculos consequentemente uma resolução simples para tais problemas.

A invenção dos logaritmos ocorreu em um momento considerado áureo para a matemática. Um pouco antes de iniciar o século XVII algumas descobertas importantes na área da matemática, física e astronomia já mostravam que este século seria recheado de manifestações científicas. Nesta ocasião, nomes consagrados tiveram seus trabalhos apresentados ao mundo como Galileu Galilei (1564-1642), Johannes Kepler (1571 - 1630), Pierre de Fermat (1601 - 1665), dentre outros.

A noção de logaritmo iniciou, supostamente, relacionada com a necessidade que os astrônomos tinham de otimizarem o tempo gasto nos cálculos e minimizarem os erros cometidos nos resultados. A trigonometria era um instrumento valioso nos cálculos astronômicos, mas ela tinha um fator desagradável: o seno, cosseno e tangente eram definidos com sete casas decimais. O produto e quociente de números com essa 
quantidade de algarismos eram muito suscetíveis a erros. Então a ideia era trocar multiplicações e divisão dos entes trigonométricos por adição e subtração equivalentes, método que ficou conhecido como prostaférese. O tempo gasto e os erros cometidos nos cálculos diminuiriam drasticamente, como o uso deste método.

A invenção efetiva dos logaritmos é creditada ao escocês John Napier (1550 $-1617)$

Convém lembrar a existência do trabalho do suiço Jobst Burgi (1552 - 1632), que também desenvolveu uma teoria de logaritmos relacionada à progressão geométrica junto com a progressão aritmética, que teria começado seis anos antes da publicação de Napier sobre logaritmos, mas só foi publicado um pouco depois da divulgação do mesmo. Napier e Burgi são considerados responsáveis pela criação dos logaritmos, cada um com sua abordagem, trabalhando de forma independente.

Embora Napier tenha não fosse considerado um matemático profissional, pois sua ocupação era pautada em questões religiosas e políticas, ficou mais conhecido como inventor dos logaritmos. A própria palavra logaritmo foi inventada por Napier a partir das palavras gregas "logo"s e "aritmos" que significam respectivamente "razão" e "números". Dos logaritmos derivou-se a função logarítmica, a qual associa a cada número positivo $x$, um número real $\log _{a} x$, onde a é um número positivo diferente de um fixo.

\section{Considerações sobre o tema}

O texto pode despertar no aluno o interesse em utilizar os logaritmos para diversos problemas não só matemáticos, mas no cotidiano, na química e na física, no momento em que ele compreende através da história que o logaritmo é uma ferramenta que simplifica cálculos. A resolução de equações exponenciais é beneficiada e reduzida a equação polinomiais, muito válida nos cálculos de matemática financeira, por exemplo.

Sugestão de atividade: após o professor propor que os alunos façam a leitura do texto pode-se abrir discursão sobre a diferença de magnitude dos terremotos quando é analisado graus diferentes.

\subsection{Trigonometria}

O fato de uma pessoa enxergar com os dois olhos permite que o mundo seja percebido de maneira tridimensional, ou seja, ela consegue ter a ideia de profundidade e consequentemente reconhece as diferentes distâncias entre os entes que estão no seu campo de visão. A percepção tridimensional se estende a todos os outros animais que enxergam com os dois olhos. A explicação se pauta na trigonometria, estudo dos lados e ângulos do triângulo. 
Além de o cérebro reconhecer como vértices de um triângulo os dois olhos e um objeto por vez, ele é conhece os ângulos formados pela linha de visão de cada olho, por que sabe a direção que os olhos estão virados, sem contar na distância entre os dois olhos.

No triângulo imaginário em questão é possível notar que a medida de dois ângulos e um lado é conhecida pelo cérebro, usando cálculos trigonométricos é possivel calcular mentalmente as distâncias aproximadas entre os objetos e o observador, ou seja, a cada vez que se olha um objeto o cérebro calcula uma equação. Na situação de vários objetos no mesmo espaço, o observador tem a perspicácia de notar o que está perto e o que está longe, logo observa o ambiente tridimensional. A figura que segue ilustra essa ideia.

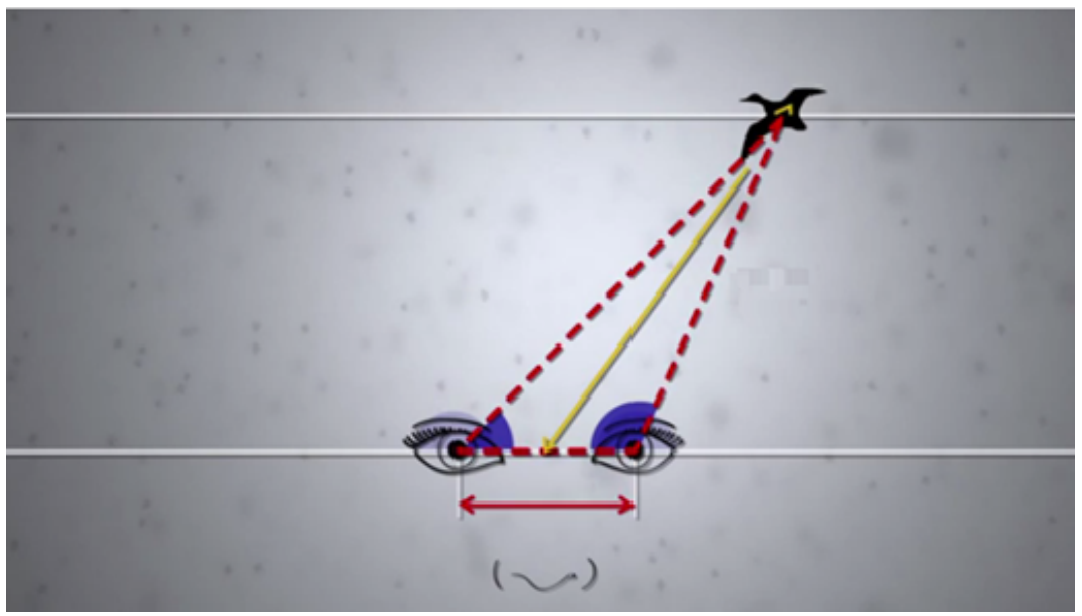

Figura 3.8: Visão - Trigonometria

(fonte: Isto é matemática T04E05 O 3D e a Trignometria). Disponível em: $<$ https://www.youtube.com/watch?v=MCTg5SsQwVg $>$. Acesso em: jul. 2016

O equipamento chamado "teodolito" segue o mesmo princípio e finalidade. Ele é usado por topógrafos para calcular grandes medidas através de cálculos trigonométricos sem se deslocar. O fato de o topógrafo não precisar ir até o ponto que deseja medir é a grande vantagem de usar um teodolito.

Não se sabe ao certo quando a humanidade começou a utilizar a trigonometria para resolver problemas práticos. O material mais antigo achado que permitia constatar o uso da trigonometria foi o papiro "Rhind" também conhecido como papiro "Ahmes", encontrado no Egito por volta de 1650 a.C. O papiro foi adquirido pelo escocês Henry Rhind e copiado pelo escriba Ahmes. Pela datação da criação do papiro é possível imaginar que algumas pirâmides foram construídas baseadas com base nos conhecimentos registrados no papiro. Entre estes, pode-se citar conceitos de inclinação da reta, um conhecimento intrínseco à estruturação de pirâmides, visto que é essencial manter a inclinação constante das faces para obter os monumentos simétricos.

Além de usar a trigonometria para construir pirâmides, os egípcios (1550 
a.C, aproximadamente) começaram a associar a sombra que uma barra vertical, com números ordenados, para um determinado comprimento da sombra resultante em uma estipulada hora do dia, dando a concepção do relógio de sol. A ideia de função trigonométrica estava naquele momento sendo usada, mas a formalização da tangente e da cotangente veio muito tempo depois.

Os babilônios e gregos deixaram sua contribuição na evolução da trigonometria, associando-a principalmente à astronomia. Não há registros sobre a pessoa que pensou em dividir o círculo em 360 partes, formando o ângulo que mede $1^{\circ}$ (um grau), mas há indícios que tenha sido o astrônomo grego Hipsicles (180 a.C.) que associou a divisão do círculo ao tempo de um ano que era aproximadamente 360 dias.

Entretanto a teoria mais aceita é que a fração da circunferência em 360 partes iguais veio de uma relação entre uma unidade de medida babilônica de comprimento (a milha, e era subdividida em 30 partes) e o tempo, ou seja, um dia tinha 12 milhas-tempo. Logo 30x12=360.

A evolução da trigonometria deu um salto durante o ano de 600 a. C. até 400 d.C., tendo sido marcado por diversos astrônomos gregos que estudaram os triângulos, como por exemplo: Tales de Mileto ( 624 - 546 a.C.) - semelhança de triângulos; Pitágoras de Samos (572 - 497 a.C.) - Teorema de Pitágoras, que levou a Relação Fundamental da Trigonometria; Hiparco de Nicéia ( 180 - 120 a.C.) - Tabela trigonométrica; Cláudio Ptolomeu de Alexandria (85 - 165 d. C.) - Aproximação do $\pi$ com quatro casas decimais.

No século IV as transformações políticas, sociais e econômicas na Europa Ocidental deram espaço, no cenário intelectual, para a entrada de hindus, árabes e persas. Os hindus escreveram sobre cordas de um círculo relacionados com o ângulo central, somente teoremas sem demonstrações, pois eles acreditavam que o Deus Surya tivesse manifestado o conhecimento através das pessoas. Com isso seria uma afronta demonstrar um ensinamento que eles tinham como incontestável. Os árabes saíram da sombra dos gregos, instituíram sua língua e foram responsáveis pelo uso do círculo de raio unitário e por organizar provas e teorias vinculadas à trigonometria. Os persas estudaram a trigonometria como um ramo da matemática dissociado da astronomia.

O estudo dos triângulos iniciado pelos gregos ficou adormecido, ou seja, novas evoluções foram pouco significativas. Apenas no ano de 1551, o matemático austríaco Rheticus definiu os pares de funções como sendo uma razão de lados de um triângulo retângulo. Em seu livro "Canom Doctrinae Triangulorum" as seis funções trigonométricas foram definidas como funções do ângulo, em vez de funções do arco, e subentendidas como razões pela primeira vez, embora ele não tenha dado nomes para seno, cosseno ou cossecante.

A palavra trigonometria aparece pela primeira vez em 1595 como título de um tratado publicado pelo matemático alemão Pitiscus, no qual ele repara as tabelas 
de Rhaeticus e moderniza o tratamento do assunto. O termo "seno" veio da abreviação de "semicorda", e cosseno apareceu como seno do complemento do ângulo. A sistematização da trigonometria veio no ano de 1464.

A produção matemática seguia para o auge, tinha-se muitas descobertas, o advento da comunicação levou os estudiosos a trocar informações e implementarem seus trabalhos com novas ideias. Sem dúvida, a criação do cálculo consolidou a trigonometria como um ramo essencial da matemática. Pelas mãos de Leonhard Euler o seno, cosseno e tangente foram inseridos na circunferência de raio unitário e passaram a ser considerados números reais.

A representação das relações trigonométricas na circunferência de raio unitário levou os matemáticos a estudarem seu comportamento de acordo com a variação do ângulo, esboçando-as como funções, sendo Gilles Roberval (matemático francês do século XVII) o primeiro a esboçar a curva do seno.

$O$ estudo das funções trigonométricas culminou com francês Joseph Fourier (1768-1830), no século XIX, atrelou os movimentos periódicos às aplicações de fenômenos cotidianos, como a música, as ondas, os movimentos circulares. Desde então é observado que os movimentos periódicos podem ser modelados usando as funções trigonométricas, e como uma bela aplicação de função, para fazer possíveis previsões.

Hoje, sons de notas musicais criados em computador são definidos a partir de funções trigonométricas, tais como o seno inserido na sua programação. Em geral, as ondas sonoras podem ser descritas por funções trigonométricas.

\section{Considerações sobre o tema}

Este texto é considerado estimulante para iniciar o conteúdo em questão, pois já traz uma experiência simples e rápida que pode ser vivenciada pelo aluno, já colocando em contato com elementos da trigonometria, conforme descrita no início do texto.

O mesmo também traz um breve panorama do desenvolvimento da trigonometria através do tempo em diversas sociedades. Este fato pode auxiliar o trabalho do professor no sentido de reforçar a matemática como uma construção humana, tendo uma parte acessível e útil, portanto, a todas as pessoas.

É válida a aplicação de uma pequena experiência acerca do primeiro tema tratado no texto, visão tridimensional.

Sugestão de atividade: a sugestão é que o professor, no primeiro momento, escolha um aluno para ser voluntário, após pedir para o aluno fechar um dos olhos, dê duas canetas de tal forma que ele segure uma em cada mão, peça para o aluno esticar os braços na altura dos olhos e posicionar as canetas horizontalmente com as pontas viradas para fora, por fim desafie o aluno a encostar as partes de trás 
das canetas. No segundo momento, peça que o aluno repita o procedimento, porém com os dois olhos abertos.

Através da execução do experimento conclua a relação entre a tridimensionalidade, a visão e a trigonometria. O texto estimula o aprendizado significativo através da redescoberta como meio de construção do conhecimento matemático produzido em diferentes contextos.

\subsection{Geometria espacial}

Praticamente, tudo que é fabricado é comercializado dentro de embalagem, mas como o empresário define a embalagem que melhor guarda seu produto? Alguns fatores são levados em consideração: o valor da embalagem, a forma de empilhamento, adequação do produto dentro da embalagem e o impacto visual.

O valor da embalagem está diretamente ligado a quantidade de material que se gasta para fabricá-la, considerando que a embalagem é a planificação de um sólido, com espessura bem definida, a minimização da área da planificação faz a embalagem custar menos.

O espaço ocupado pelo empilhamento dos produtos embalados é de suma importância, pois implica diretamente na estocagem e transporte, ou seja, a melhor embalagem é aquela que que o empilhamento ocupa o menor espaço. A adequação do produto dentro da embalagem está relacionada com a capacidade de armazenamento, isto é, o volume de produto que a embalagem suporta.

Considerando sólidos com mesmo volume, a esfera apresenta a menor área, mas é evidente que há muita perda de espaço no empilhamento. Dentre os sólidos que otimizam o espaço no empilhamento, os poliedros, o cubo apresenta a menor área.

Então por que a maioria das embalagens encontradas no mercado são do formato de um paralelepípedo? A resposta está na estratégia de venda, quanto maior a face frontal da embalagem, mais ela será vista e maior a chance do cliente adquirir o produto.

A geometria espacial é a parte da matemática que estuda os objetos tridimensionais, ou seja, que têm três dimensões: altura, largura e comprimento. As civilizações antigas tinham conhecimentos de geometria espacial, vide as grandes pirâmides construídas cerca de 2600 a.C., que abrigavam os túmulos de faraós. No Egito, existem cerca de 80 pirâmides com bases quadradas bastante precisas. As três maiores pirâmides do Egito são a de Miquerinos, a de Quéfren e a de Quéops, a maior delas, que ao ser terminada media 146,7 metros de altura e 230 metros na aresta da base, inclusive o quadrado que forma a base da pirâmide foi estudado por engenheiros modernos que concluíram que os lados e os ângulos retos tinham um erro estimado na ordem de $10^{-5}$. 


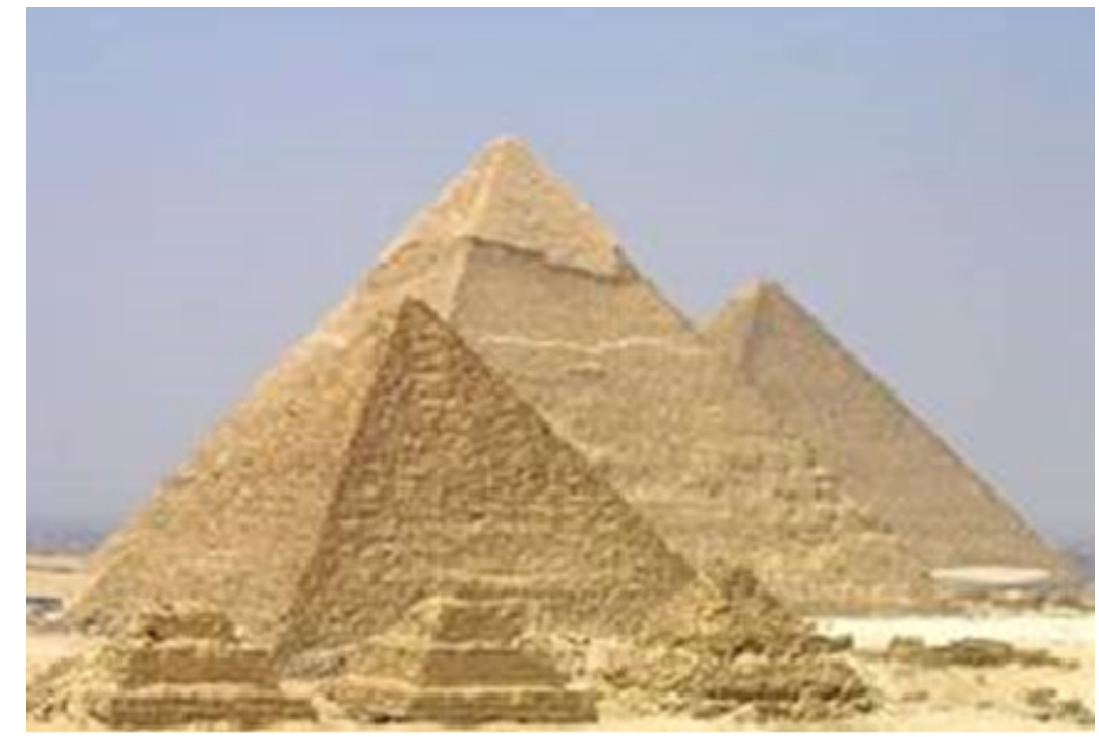

Figura 3.9: Miquerinos, Quéfren e Quéops

(fonte: Pirâmides de Gizé - Só história). Disponível em:

<http://www.sohistoria.com.br/ef2/egito/piramides.php>. Acesso em: out. 2016

Este fato mostra que as pirâmides foram construídas com um grau de precisão muito alto, e que sem conhecimentos geométricos não seria possível construir um monumento desta magnitude.

A Babilônia também é considerada o berço da matemática, pois o desenvolvimento matemático da região era bastante avançado, devido ao fato da localização geográfica ser privilegiada. A Babilônia fazia parte das grandes rotas comerciais, daí os viajantes levavam a gama de conhecimentos adquiridos em suas cidades para o território babilônico.

Dois papiros egípcios são protagonistas na história da evolução da geometria espacial. O primeiro é o papiro Moscou. Escrito por volta de 1850 a.C., possui 25 problemas, mas o problema que mais chama a atenção é sobre o cálculo de um tronco de pirâmide. A resolução deste problema não faz referência à fórmula que hoje é amplamente utilizada para calcular o volume de um tronco de pirâmide de base quadricular. Muitos pesquisadores defendem que os escritos do Papiro de Moscou sobre pirâmides serviram de orientação para construções de algumas pirâmides.

O outro papiro, chamado "Rhind", escrito por volta de 1650 a.C. é um texto matemático que possui 85 problemas com soluções, dentre os quais alguns estão relacionados com o volume de paralelepípedo e cilindro, cujas soluções usam o produto da área da base pela altura. A área da circunferência não era tão precisa quanto é hoje, mas os egípcios faziam uma aproximação que para eles era satisfatória.

Os egípcios e os babilônios usavam métodos geométricos para resolver problemas, porém a geometria propriamente dita é grega; tanto é que a palavra "geometria" 
vem dos vocábulos gregos geo e metria que significam terra e medida, respectivamente. Sabe-se que o primeiro grande geômetra grego, Tales de Mileto, tinha influência da matemática egípcia, mas não se sabe ao certo como aconteceu o transporte das informações de uma região para a outra, e nem quem foi o responsável por tal transição; sabe-se somente que aconteceu e que a matemática egípcia motivou a criação da geometria grega.

Os filósofos e geômetras gregos, como Euclides, Pitágoras, Platão e Arquimedes, tiveram um papel fundamental na história da matemática, em especial na geometria. Euclides de Alexandria (330 a.C. - 260 a.C.) foi responsável por produzir uma obra prima da matemática, "Os Elementos", tal obra composta por treze livros que reúnem quase toda a matemática produzida na época, além de fazer um tratamento axiomático e demonstrativo de temas elementares da matemática.

Em "Os Elementos", Euclides abordou a geometria espacial nos últimos três livros, como definições de paralelismos e perpendicularidade de retas e planos, volumes de pirâmides, cones e esferas, além de estudos sobre os sólidos conhecidos como "poliedros de Platão".

\section{Considerações sobre o tema}

A parte dedicada ao conteúdo de geometria espacial, proposta para o Ensino Médio é muito ampla, pois abarca grande parte dos estudos dos elementos geométricos de poliedros como prismas e pirâmides e os corpos redondos como a esferas, cilindros e cones. Então o texto traz uma ideia geral sobre a geometria espacial.

Sugestão de atividade: recomenda-se que este texto seja lido pelos alunos após o termino da explicação do conteúdo, pois existe partes do texto que é necessário conhecimento de alguns elementos da geometria espacial. Nos últimos vinte minutos o professor pode aplicar o texto e propor um exercício. Dessa forma, pode estimular os alunos, pedindo que calculem o volume da maior pirâmide do Egito, mostrada no texto.

\subsection{Geometria analítica}

O século XVII foi marcado pela revolução científica na qual predominaram vários pensamentos renascentistas. A ciência passou a ser vista de uma outra maneira: não era restrita ao misticismo e à religião. A pessoa humana dotada de inteligência se tornou valorizada neste cenário como um ser pensante que questiona e o empirismo foi substituído pelo aprimoramento da técnica. A matemática, como um instrumento da ciência e produção artistística, acompanhou essa evolução. Em Os Elementos, Euclides a parte de geometria era o principal objeto de estudo até então, mas passou a ser 
obsoleto por causa da falta de funcionalidade. A comunidade científica precisava de uma geometria mais prática que auxiliasse a astronomia, a física e construções de mapas de maneira concreta e prática.

A nova geometria chamada de "geometria analítica" ou "geometria cartesiana", veio para a necessidade da ciência na época, sendo determinante para o avanço.

O filósofo e matemático francês René Descartes (1596 - 1650) é conhecido como o pai da geometria analítica, por dar tratamento formal e simbólico do assunto em um dos apêndices de sua célebre obra filosófica, Discours de la Méthode pour Bien Conduiresa Raison howardeves et Chercher la Véritédans les Sciences (Discurso do método para bem conduzir a razão e procurar a verdade nas ciências) de 163\%. O apêndice intitulado La géométrie tem cerca de 100 páginas e foi concebido para dar ilustrações de seus métodos filosóficos gerais sobre deduções lógicas.

Devido à ampla reprodução do seu tratado filosófico, a geometria analítica contida nele chegou ao conhecimento de seus contemporâneos. Descartes usou em seu trabalho sobre geometria analítica uma simbologia bem parecida com a que usamos hoje. As edições comerciais do Tratado de Descartes mais conhecido como apenas "Discurso do Método" não contém os três apêndices, provavelmente para preservar o teor filosófico que a obra possui.

A geometria analítica moderna não é um ramo da geometria, mas sim um método da mesma, pelo fato de propiciar à pessoa que a estuda uma maneira de resolver problemas geométricos usando a álgebra que, em muitos casos, deixa o caminhar para a solução menos penosa. Essa é sua maior virtude.

Concomitantemente à época que Descartes viveu, Pierre de Fermat (1601 - 1665) estudou equações algébricas relacionadas a coordenadas cartesianas de forma independente. Contribuiu imensamente para a evolução da geometria analítica, embora a notação utilizada em sua publicação sobre o assunto seja arcaica, ou seja, não é mais usada nos meios acadêmicos, comparada com a simbologia usada por Descartes.

O trabalho de Fermat versava sobre curvas mais complexas sobre o plano cartesiano, chegando assim à equação geral da circunferência, e ilustrou nos gráficos algumas cônicas. Enquanto o estudo de Descartes baseava-se em levar a geometria para a álgebra. Fermat fez o caminho inverso: partia da álgebra para encontrar lugares geométricos.

\section{Considerações sobre o tema}

Destaca-se que os estudantes desta etapa final do ensino básico estão familiarizados com o plano cartesiano; desta forma não foi inserido no texto a parte que trata da origem do plano cartesiano.

Pode ser interessante que a leitura do texto sirva de introdução motiva- 
cional para a aula de geometria analítica. Uma razão é que se considera importante conhecer as origens históricas da geometria analítica porque apesar de essa ser uma das áreas mais recentes da matemática que foram desenvolvidas e inseridas nos currículos escolares, isto é, cerca de quatro séculos, ganhou um espaço significativo na esfera educacional, bem como nas pesquisas acadêmicas.

Outro ponto que reforça a validade da apresentação deste texto é o fato de que atualmente tem-se ampliado a instalação de laboratórios de ensino de matemática nas escolas, sendo frequente a existência de um material chamado "geoplano", criado pelo professor Caleb Gattegno (1911 - 1988). Um dos méritos de tal material é poder ser associado ao plano cartesiano, servindo assim de tabuleiro para jogos criados a partir de conteúdos de geometria analítica.

Sugestão de atividade: assim como Descartes se propôs a levar a geometria à álgebra, o professor pode percorrer caminho similar utilizando conhecimentos de geometria básica conhecidas pelos alunos, como por exemplo calcular a área de triângulo retângulo. Isso é feito a partir dos dados dos pontos onde estão localizados os vértices. Usando a fórmula da distância entre dois pontos, vista na geometria analítica, calcula-se as medidas dos lados, ou seja, catetos e hipotenusa. Com a fórmula da geometria plana para calcular a área do triângulo, considerando um cateto como base e outro como altura, o aluno pode resolver a questão.

\section{Considerações sobre os textos}

Pode-se observar que alguns textos estão relacionados com temas contemporâneos, como o texto sobre matrizes, de modo que se optou por dar exemplos atuais, mas não deixando de fazer o apanhado histórico, que é o foco deste trabalho. Outros conteúdos, como geometria analítica, são abordados no texto com o desenvolvimento histórico.

Um outro ponto a destacar é que todos os textos já trazem sugestões de como o professor pode utilizá-los em sala de aula, que pode contribuir para facilitar o trabalho do professor junto aos alunos.

Uma sugestão adicional, quanto a aplicação dos textos, é que os professores de matemática da mesma instituição, no momento de suas coordenações pedagógicas, discutem entre si o impacto dos textos, levando em consideração a forma abordada, as adaptações feitas no momento da aplicação e se os alunos através da história se mostraram mais interessados em aprender os conteúdos programáticos.

Acredita-se que além dos alunos, os textos podem motivar os professores, buscando novas fontes ou adaptando/criando seus próprios textos.

Enfim, reforça-se a crença no potencial motivador desses textos que poderá ser ampliado mais ainda com reflexões, atuando sobre os textos. 


\section{Capítulo 4}

\section{UMA PESQUISA EMPÍRICA: OPINIÃO DE PROFESSORES SOBRE HISTÓRIA NO ENSINO}

Para se ter uma ideia inicial da possibilidade de haver ou não algum impacto no uso dos textos produzidos neste trabalho no aprendizado dos alunos do Ensino Médio, optou-se por fazer uma pesquisa de campo relativa à história da matemática em geral.

Uma vez que o produto desta dissertação, o conjunto de textos, seja um meio de inserir a história na aula de matemática, convém verificar, inicialmente, as possíveis aproximações entre professores de matemática e história em sua prática docente. Assim, esta pesquisa é considerada importante, no sentido de poder investigar a opinião dos professores quanto à relevância que eles dão à história da matemática como recurso didático.

Os resultados da pesquisa poderão sinalizar, assim, se os textos têm potencial para serem aplicados em sala de aula. Os resultados da pesquisa empírica, além de ajudarem na compreensão da prática dos pesquisados em diferentes realidades escolares, eles poderão confirmar a importância do uso da história da matemática na prática dos professores do Ensino Médio.

A pesquisa empírica está no formato de uma entrevista aplicada junto ao um grupo de professores de matemática, com o objetivo de investigar a importância dada à história da matemática como estratégia de ensino e a percepção dos professores quanto ao potencial dos textos em suas práxis.

Através da experiência profissional e acadêmica que os professores entrevistados costumam trazer, pode-se inferir que eles podem ter também a sensibilidade de observar, no dia a dia o aumento do interesse dos alunos perante a matemática e o aumento da aprendizagem significativa.

Passa-se a descrever a pesquisa. 


\subsection{Metodologia de pesquisa empírica}

Para realizar a pesquisa, escolheu-se como amostra o grupo de professores atuantes no Ensino Médio, em escolas públicas do Distrito Federal. Uma vez que os textos produzidos e apresentados foram feitos com a intenção de proposta de publicação posterior à Secretaria de Educação do GDF, considerou-se ser esse o universo mais efetivamente adequado. Além disso, pela mesma razão, a escola do nível de abrangência foi restrita ao Ensino Médio. Para que a amostra fosse representativa, optou-se por convidar professores das mais diferentes regiões e de maiores cidades, para que o resultado melhor expressasse o que ocorre atualmente neste Distrito.

Dessa forma, foram escolhidos sete professores atuantes no Distrito Federal que lecionam ou lecionaram no Ensino Médio dentre os que se propuseram a responder um questionário, cujo modelo é mostrado no apêndice. O referido questionário é composto de seis blocos temáticos de aspectos abordados traduzidos em seis questões, as quais serão descritas mais adiante.

Tal pesquisa compõe um estudo exploratório, o qual versa sobre as opiniões dos professores quanto ao uso da história da matemática como recurso didático no ensino a partir de um dos textos.

Através dos itens do questionário, investigou-se: o perfil do entrevistado; a relação que o entrevistado tem com a história da matemática desde o ensino básico, passando pelo superior e chegando as suas práxis; o posicionamento quanto a relevância da história no ensino-aprendizagem da matemática; a utilização da história da matemática como estratégia de ensino; e os prováveis dificultadores que coíbem o uso da história como recurso didático na aula de matemática.

A primeira questão proposta tem o enunciado mostrado a seguir:

\section{"PERFIL:}

Tempo de magistério: anos Sexo: () $M() F$

Trabalha em instituição pública ( ) sim ( ) não

Caso sim, em qual regional de ensino

Sua formação superior foi: ( ) licenciatura em matemática ( ) bacharelado em matemática ( )outra (qual?)

Como se pode constatar, essa questão discorre sobre aspectos que permitem elaborar um perfil dos professores entrevistados, a fim de que se possa compreender o contexto onde ele atua e sua provável experiência com a história da matemática.

A segunda questão está transcrita a seguir:

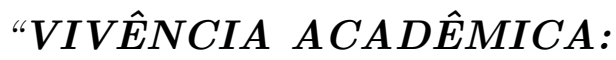

Enquanto estudante ANTES DO ENSINO SUPERIOR, você teve aulas ou atividades envolvendo a história da matemática?

( ) Sim ( ) Não Caso tenha respondido sim, que atividades?" 
Pode-se observar que a segunda questão remete ao contato com a história da matemática durante o ensino básico, quando os professores ainda eram estudantes. Considera-se que essa é uma maneira pertinente de verificar se a atual prática do professor entrevistado pode estar ligada a experiências anteriores, talvez provocadas por empatia com seus alunos, no sentido de pensar sua prática colocando-se no lugar de seus alunos, quanto às oportunidades de diversificação das atividades desenvolvidas na sala de aula.

Segue a terceira pergunta:

"Na sua graduação ou pós-graduação, você cursou alguma disciplina sobre história da matemática? Caso sim, a disciplina abordou: ( ) Dados bibliográficos de matemáticos. ( ) Abordagem social político cultural da criação das teorias. ( ) Breve cronologia de resultados obtidos no tema ensinado. ( ) Apresentação de uma situação problema antiga e as formas de resolução ao longo da história ( ) Algumas anedotas sobre matemáticos ligados ao conteúdo. () outras (quais?) Caso não, você gostaria que tivesse? ( ) Sim ( ) Não. Por que?

Com esta questão, busca-se verificar, o quanto o fato do professor entrevistado ter cursado ou não a disciplina história da matemática, ou mesmo conteúdos e atividades a ela relacionados, durante o ensino superior, pode ter influenciado ou não na postura adotada em sala de aula pelo professor quanto à história; verifica também o posicionamento do mesmo frente a possíveis prejuízos causados, na sua formação acadêmica e profissional, pela falta do tema em questão.

Apresenta-se agora a quarta questão.

"Você acredita que a história da matemática inserida nas aulas pode ajudar o aluno na aprendizagem da disciplina matemática? Por quê?

Aqui, considera-se que a experiência docente do professor pode desenvolver no mesmo uma sensibilidade para perceber, muitas vezes, as necessidades de seus alunos durante as atividades em cada conteúdo. Dessa forma, a questão busca investigar o impacto positivo da história da matemática no aprendizado do aluno pelo olhar do professor, levando em consideração o grau de habilidade que ele possui para tecer opiniões sobre o seu aluno. A quinta questão está expressa a seguir.

"Você utiliza em suas aulas ou atividades a história da matemática? ( ) Sim ( ) Não Caso sim, de que maneira? Caso não, por que?

Esta questão é considerada a mais relevante, pelo fato de que, através dela, é possível observar as falas dos professores entrevistados quanto à história da matemática, ao impacto dos fatos relatados nas questões anteriores na efetiva utilização da história 
da matemática, à alegação do motivo pelo qual o entrevistado não utiliza a história da matemática nas aulas e ao modo como a história da matemática é inserida na classe. $\mathrm{Na}$ experiência docente da autora, existe a constatação feita através de comentários informais de colegas de profissão, de que alguns tiveram história em seu currículo, mas não a utilizam, bem como o contrário, ou seja, mesmo não fazendo parte de sua formação, buscam alternativas metodológicas para suas práxis que inclui a história.

Transcreve-se, agora, a próxima questão.

"Caso você considere que os professores enfrentam dificuldades para utilizar a história no ensino de matemática no seu cotidiano profissional, o que faz, a que tipo de material e fonte de consulta deveria ter acesso e o que acha que deveria/poderia ser feito para melhorar a situação?"

Pelas respostas dos professores nessa questão será possível observar ou não indícios de se o produto desta dissertação, um conjunto de textos sobre a história da matemática voltado para o Ensino Médio, permite converter-se em um material em potencial auxiliar da prática do professor quanto a enfrentar dificuldades perante a perspectiva de utilização da história no ensino de matemática.

A última questão foi elaborada para permitir uma resposta livre, conforme o enunciado que se apresenta:

"Por favor, explique qual é para você a importância/validade/necessidade da história no ensino de matemática. Caso queira acrescentar alguma opinião ou comentário, fique a vontade para apresentá-lo aqui."

O intuito desse pedido é verificar a percepção dos professores entrevistados sobre aspectos da história da matemática como estratégia didática, no Ensino Médio.

Com esses dados, acredita-se poder elaborar um arcabouço da posição dos professores acerca do texto no que diz respeito aos objetivos desta dissertação. Para desenvolver a pesquisa, observaram-se os seguintes passos:

Em primeiro momento, foi feita uma abordagem dos professores que tinham o perfil compatível com o público-alvo desta pesquisa, a respeito do interesse em colaborar respondendo um questionário. Os professores, na ocasião deste convite, mostraram-se entusiasmados. Os questionários foram propostos por e-mail, a respostas também foram encaminhadas pela mesma via.

Acreditava-se que os questionários pudessem ter sido respondidos e enviados no tempo médio de quinze dias, de modo que se expressou esse prazo no e-mail de envio.

Após a aplicação dos mesmos, pretende-se sistematizar a organização das respostas, o que consistirá tanto em tabular para inferências estatísticas, quanto para estabelecer categorias de respostas e proceder à análise das mesmas.

Feito isso, serão apresentados os resultados e posteriores conclusões e encaminhamentos. 


\subsection{Resultados da pesquisa empírica}

Inicialmente, constata-se que a perspectiva de retorno ocorreu, e também no prazo pensado. Além disso, nenhum participante da pesquisa declarou ter tido dificuldade em compreender e responder às perguntas do questionário.

Neste tópico, passa-se a discutir os resultados dos dados coletados a partir das respostas dos professores ao questionário. Optou-se por fazer a análise das respostas questão a questão, fazendo as observações e inferências que fossem cabíveis e pertinentes a partir do que foi constatado.

No quadro que segue, é mostrado o conjunto de dados que permite esboçar o perfil dos entrevistados.

\begin{tabular}{|l|l|l|l|l|l|l|l|}
\hline Professor/dados & $\mathbf{0 1}$ & $\mathbf{0 2}$ & $\mathbf{0 3}$ & $\mathbf{0 4}$ & $\mathbf{0 5}$ & $\mathbf{0 6}$ & $\mathbf{0 7}$ \\
\hline $\begin{array}{l}\text { 1. Tempo de } \\
\text { magistério } \\
\text { (anos) }\end{array}$ & 07 & 10 & 10 & 04 & 10 & 17 & 08 \\
\hline 2. Sexo & $\mathrm{M}$ & $\mathrm{F}$ & $\mathrm{M}$ & $\mathrm{F}$ & $\mathrm{F}$ & $\mathrm{M}$ & $\mathrm{M}$ \\
\hline $\begin{array}{l}\text { 3. Trabalha em } \\
\text { instituição } \\
\text { pública? }\end{array}$ & Sim & Sim & Sim & Sim & Sim & Sim & Sim \\
\hline $\begin{array}{l}\text { 4. Cidade de } \\
\text { trabalho }\end{array}$ & $\begin{array}{l}\text { Recanto } \\
\text { das } \\
\text { Emas }\end{array}$ & Sobradinho & $\begin{array}{l}\text { São } \\
\text { Sebastião }\end{array}$ & Ceilândia & Paranoá & $\begin{array}{l}\text { Plano } \\
\text { Piloto/ } \\
\text { Cruzeiro }\end{array}$ & Planaltina \\
\hline $\begin{array}{l}\text { 5. Formação } \\
\text { superior }\end{array}$ & LM & LM & LM & LM & LM & LM & LM \\
\hline
\end{tabular}

Figura 4.1: Perfil dos professores entrevistados.

Considerando que os cursos de Licenciatura do Distrito Federal têm incluído a História da matemática, no máximo, nos últimos cinco anos, pode-se considerar que dificilmente os entrevistados tiveram em seu currículo de graduação a referida disciplina. Por outro lado, a pós-graduação é muito forte na cultura acadêmica dos professores do distrito, o que leva à possibilidade de algum desses professores terem tido contato com a disciplina.

Além disso, verifica-se que o sistema educacional do Distrito Federal não somente estimula e recomenda fortemente, como também promove a viabilidade da participação dos professores de seus quadros em eventos relativos à suas áreas, tanto no nível local, regional, nacional, quanto internacional. Isto possibilita a esses professores um acesso mais efetivo às pesquisas mais recentes sobre Educação matemática, o que inclui a história.

Conforme visto no capítulo referente ao referencial teórico, a história da matemática é uma tendência da Educação matemática que é estimulada para a prática dos professores. Juntando a isso as oportunidades de acesso às produções mais diversas e mais atuais nesta área, vislumbram-se possibilidades de contato dos professores com 
a história, portanto, uma visão objetiva na análise dos textos.

Quanto ao segundo aspecto, temos um equilíbrio entre professores e professoras, sendo três mulheres e quatro homens, o que sinaliza que o gênero não deverá imputar diferenças significativas nos resultados. Passar-se-á ao terceiro aspecto.

O terceiro aspecto busca saber se o docente atuou em outros tipos de instituição. Lembrando que algumas delas têm foco específico - Ensino Profissionalizante, preparação para concursos ou vestibulares, colégios militares etc. Conta-se com a possibilidade do docente não poder introduzir inovações significativas em sua práxis. Assim têm-se situações em que o professor não pode extrapolar o currículo imposto. Todas elas estão subordinadas aos documentos oficiais (BRASIL, 1996, 2013) e em suas orientações, recomenda-se práticas inovadoras e condizentes com a época atual. Considera-se que essas situações possíveis contribuem para ratificar a intenção da pesquisa em investigar a opinião dos professores atuantes na escola pública do distrito Federal, visto que se almeja submeter o trabalho a publicação posterior à Secretaria de Educação do Distrito Federal.

Percebe-se no quarto aspecto que, como as escolas de lotação dos entrevistados foram selecionadas de modo a estarem localizadas em diferentes Regiões Administrativas, pode-se inferir que, assim como a questão do gênero, o local onde os professores atuam, deve permitir, por seu caráter de abrangência regional, resultados mais fiéis nas análises da pesquisa.

As respostas ao quinto aspecto tabuladas no quadro revelam que todos os professores entrevistados são licenciados. Esse fato permite eliminar de nossa análise a falta da formação dos professores no que concerne às disciplinas de cunho pedagógico, e isso aumenta as possibilidades de contato do professor com a história. Aqui, encerra-se a análise do primeiro bloco de aspectos da questão referente ao perfil docente.

Passando à questão seguinte, constata-se nas repostas coletadas, que nenhum dos entrevistados declarou ter tido aulas ou atividades envolvendo a história da matemática enquanto estudantes do ensino básico. Assim, é comum ocorrer que este professor, também não inclua em sua prática docente os conteúdos e atividades que não teve, ou que não sejam solicitados pela direção da instituição. No entanto, mesmo nesta situação, o professor pode ser um constante buscador de aperfeiçoamento de sua prática, o que pode levá-lo à busca de novas alternativas de trabalho, e para isso já dispõe de alguns trabalhos expostos no capítulo 1. Volta-se a lembrar que a recomendação dessas práticas inovadoras consta nos documentos oficiais voltados para o ensino (BRASIL, 2013, 2014), o que leva a considerar que os docentes também acatem essas recomendações.

Com respeito aos resultados da segunda questão, quatro entrevistados, durante a graduação ou pós-graduação, cursaram alguma disciplina sobre história da matemática que envolvia: dados bibliográficos de matemáticos; breve cronologia de 
resultados obtidos no tema ensinado; apresentação de uma situação-problema antiga e as formas de resolução ao longo da história; e algumas anedotas sobre matemáticos ligados ao conteúdo. Observa-se aqui que nenhum desses respondentes vivenciou atividades que concerniam a uma abordagem sociopoliticocultural da criação das teorias, o que se constitui em um dos aspectos mais relevantes para a compreensão de como evoluiu o desenvolvimento das ideias matemáticas.

Já os três entrevistados que, durante a graduação ou pós-graduação, não cursaram disciplinas sobre história da matemática, assinalaram que gostariam que as tivessem na grade curricular, conforme as respostas cujas ideias foram categorizadas e são mostradas a seguir.

Todos os professores remeteram à história como forma de compreender o desenvolvimento dos conceitos matemáticos. Destaca-se aqui que todos valorizaram o segundo tipo de atividade, mesmo que não a tenham tido. Apresentam-se as transcrições dos trechos das referidas respostas:

“... o contexto histórico contribui para a compreensão dos conceitos matemáticos..." (prof. 1).

"Acreditam que começar um conteúdo pelas origens, estudando o modo que determinado raciocínio era utilizado anteriormente e como é utilizado hoje, facilita a compreensão do mesmo" (prof. 4).

"Pressupõe que seria uma abordagem importante para ampliar o conhecimento e dar mais significado a minha aprendizagem de matemática, e ainda, auxiliaria como professora para que pudesse motivar os meus alunos por meio da contextualização histórica" (prof. 5).

Estas constatações permitem vislumbrar uma possibilidade de aceitação de novos materiais que venham a ser propostos a esses professores, tais como os textos produto desta dissertação. Além disso, autores como D'Ambrosio (2011), Menezes (2014) e Miguel (1993) trazem argumentações nessa direção, o que coloca os professores em sintonia com esses autores no que se refere a esse aspecto. Um dos respondentes remeteu à questão da dinamização das aulas, conforme, pode-se ler a seguir:

“... , além de ser um recurso bastante interessante para dinamizar as aulas" (prof. 1).

Destaca-se ainda que um docente remeteu, em sua resposta, ao aspecto motivador da história, conforme o trecho transcrito:

“... me auxiliaria como professora para que pudesse motivar os meus alunos 
por meio da contextualização histórica" (prof. 5).

A terceira questão versou sobre as possibilidades de contribuição da história para a aprendizagem de matemática. Todos os professores entrevistados declararam acreditar que a história da matemática inserida nas aulas pode ajudar o aluno na aprendizagem da disciplina matemática. As justificativas remeteram a diversos aspectos: cinco professores expressaram a possibilidade de compreender o surgimento das ideias matemáticas ao longo do contexto histórico conforme transcrito:

"Considero que o contexto histórico contribui para a compreensão dos conceitos matemáticos..." (prof. 1).

"Para mostrar que a matemática surgiu da necessidade de resolver problemas cotidianos" (prof. 3).

“... ajuda na compreensão do conteúdo, visto que são estudados modos anteriores de como se pensava em determinado raciocínio e como é feito nos dias de hoje" (prof. 4).

"Porque podem entender os princípios, perceber que a matemática evoluiu junto com a história, inclusive sofrendo influência dos movimentos que modernizaram a indústria entre outros... O entrelaçamento entre a matemática e os contextos históricos e sociais possibilitam significar a aprendizagem" (prof. 5).

"Sim, pois o aluno compreende melhor o conteúdo quando imerge no contexto em que se desenvolveu a teoria" (prof. 7).

Pesquisadores como, D’Ambrosio (2011), Mendes (2001) e Miguel (1993) focam esse aspecto do uso da história na matemática. Desse modo, os fragmentos de respostas apontam que esses professores reforçam as ideias desses autores pois, conhecer a evolução de uma ideia dentro de um contexto facilita a compreensão da mesma.

Um segundo aspecto que emergiu na leitura das respostas remete à motivação para aprender as ideias matemáticas, captamos quatro trechos que confirmam isso conforme passam a ser transcritos:

"A história da matemática faz com que o aluno tenha mais interesse pelo conteúdo" (prof. 2).

"Além de tornar a aula mais interessante, como foi dito anteriormente, ajuda na compreensão do conteúdo" (prof. 4). 
"Aproximando o aluno do assunto a ser ministrado, estreitamos a relação dele com o conteúdo a ser trabalhado. Esta intimidade pode ser útil para despertar seu interesse e aumentar sua dedicação aos estudos" (prof. 6).

Esses depoimentos apontam que a maior parte dos professores entrevistados mostram uma visão positiva da inserção da história da matemática como elemento motivador. Além de convergir com as ideias tanto de pesquisadores quanto de documentos oficiais como o Currículo em Movimento (DISTRITO FEDERAL, 2014), convergem também com a ideia inicial da autora, no sentido desta motivação ser viabilizada através de textos. Finalmente um professor referiu-se à história como um elemento que pode contribuir para a compreensão da matemática como produção humana, conforme sua resposta:

"Sim, porque podem entender os princípios, perceber que a matemática evoluiu junto com a história, inclusive sofrendo influência dos movimentos que modernizaram a indústria entre outros. Também é importante percebemos que a matemática não é uma ciência pronta, que se constrói constantemente para atender as necessidades tecnológicas, de desenvolvimento intelectual, de ensino e aprendizagem" (prof. 5).

Aqui, convém lembrar que qualquer área do conhecimento também se constitui em produção humana, o que torna a sua compreensão importante no que se refere aos processos de produção. Pode-se, então, concluir que os professores entrevistados valorizam a história da matemática inserida nas aulas, por poder ajudar o aluno na aprendizagem da disciplina matemática.

Na questão quatro, a autora perguntou se o professor utilizava a história da matemática em suas aulas ou atividades de ensino. Dois professores declararam não utilizar a história da matemática em sua prática na sala de aula, alegando em suas respostas que:

"O currículo é muito extenso, não sobra tempo e essas atividades são deixadas em segundo plano" (prof. 3).

"Por faltar-me o conhecimento, pois só tive esse ensino há mais de 20 anos e nunca tive tempo ou me foi proporcionado um estudo novamente. Também, porque as escolas hoje em dia, principalmente as particulares, prezam por resultados e cumprimento de conteúdos propostos. Como é muito extensa a grade curricular, não sobra tempo para esse tipo de abordagem" (prof.6).

Vale destacar que o perfil dos entrevistados revelou a falta da história no currículo da formação de alguns, o que explica a ausência da mesma em sua prática. 
Isso também sinaliza a falta de busca de outras alternativas metodológicas, além da sua bagagem acadêmica, para sua prática docente.

Os cinco demais entrevistados declararam utilizar a história da matemática nas suas aulas, explicando a maneira de fazê-lo, conforme as transcrições mais adiante. Todos eles declararam utilizar a história para introduzir conceitos. As diversas formas citadas sinalizam que textos históricos como os que se pretende publicar são passíveis de serem utilizados na prática docente, convergindo com as ideias da pesquisadora. Apresentam-se as transcrições das respostas:

"Trabalho sempre que possível com o contexto histórico para introduzir conceitos. Quando o tempo e o conteúdo permitem, desenvolvo atividades para que os alunos percebam como se utilizavam os conceitos com o passar do tempo"(prof. 1).

"Apresentando uma situação-problema antiga e as formas de resolução ao longo da história ou contando anedotas sobre matemáticos ligados ao conteúdo" (prof. $2)$.

"Não uso em todas as aulas, mas sempre que possivel, e que julgo melhor, introduzo um conteúdo falando um pouco da história do mesmo, dando exemplos e fazendo uma conexão de como é o raciocínio atual" (prof 4).

"Utilizo pouco, geralmente na introdução dos conteúdos, gosto de falar sobre algumas curiosidades e sobre o contexto que envolveu ou envolve o conteúdo a ser ensinado" (prof. 5).

"Costumo mostrar para o aluno uma breve biografia dos principais nomes relacionados à teoria e em que contexto aquela descoberta teve alguma influência $e$ utilidade" (prof. 7).

As transcrições mostram diversas formas de usar a história para introduzir um conteúdo. Além disso, o prof. 1 enfatiza a lucidez de adequar este recurso às suas possibilidades.

Um tema que emergiu das respostas e vale citar por levantar um aspecto interessante relacionado à condição profissional, diz respeito às ideologias que as autoridades escolares inserem no contexto, tais como cumprimento do conteúdo de da carga horária, conforme expressado na resposta:

"Mas nem sempre é possivel porque essas aulas demandam tempo e há muita pressão da escola para que consigamos ensinar a maior quantidade possível de conteúdo, despreocupando-se, de certo modo, com a qualidade do ensino" (prof. 5). 
Passando à questão cinco, onde os professores são solicitados a narrar as dificuldades que enfrentam para utilizar a história no ensino de matemática no seu cotidiano acadêmico, alguns entrevistados declararam acreditar na falta de preparo do professor para utilizar este tipo de estratégia de ensino da matemática, ou dificuldades semelhantes, como é constatado em suas respostas:

"É uma questão que passa principalmente pela formação do professor" (prof. $1)$.

"Acredito que o material de pesquisa em história da matemática seja insuficiente" (prof. 2).

"O processo de construção histórico da matemática e de construção matemática muitas vezes é deixado de lado, porque valorizam-se mais os resultados do que os caminhos, a aprendizagem em si" (prof. 6).

Destaca-se a seguir, na resposta do prof. 4, a necessidade da existência de mais textos históricos voltados para explicar o surgimento e desenvolvimento de conteúdos matemáticos específicos para o Ensino Médio. Essa ideia coaduna com as inspirações dessa autora, o que sugere um reforço da validade de produzir os textos históricos para este nível de ensino com pretensões motivadoras. Reproduz-se a resposta:

"Como foi dito anteriormente, não são em todos os conteúdos que falo sobre a história por trás do mesmo, e isso acontece devido à dificuldade em encontrar a história específica de cada conteúdo" (prof. 4).

Ainda na questão, é perguntado ao professor que ações, materiais e fontes de consulta considera úteis ou adequados ao mesmo no sentido de superar as dificuldades apresentadas. Segundo os entrevistados, o problema poderia ser enfrentado, ou até solucionado, com participação em cursos de aperfeiçoamento, ou mesmo ter a história da matemática como disciplina constando na grade curricular do curso de licenciatura. Os entrevistados apontaram em suas respostas que:

"Mas o primeiro passo é o acesso ao professor a alguns modelos de metodologias que utilizem a história da matemática como recurso didático. Depois é necessário rever os cursos de licenciatura e a formação continuada dos professores" (prof. 1).

"Poderiam ocorrer mais atividades extraclasse voltadas ao ensino da história da matemática na escola" (prof. 3). 
"Para facilitar essa situação acredito que pelo menos uma matéria acerca de história da matemática deveria ser obrigatória na graduação em licenciatura, além de um material específico para ser utilizado pelos professores que atuam em sala de aula" (prof. 4).

"Creio que precisa ser discutido o currículo de matemática, porque vemos que há uma sobrecarga de conteúdos que são ensinados de forma rápida, repetida e sem sentido. As tecnologias evoluíram, as necessidades humanas evoluíram, no entanto, ainda continuamos mantendo o mesmo currículo e forma de ensinar, por isso há um grande desafio para quem é docente atualmente, que é significar os conteúdos matemáticos, para que os estudantes consigam aprender e utilizar aquele conteúdo para sua formação integral. O desafio de fazer da matemática um instrumento para a formação" (prof. 5).

"Na rede pública, poderia haver cursos dessa natureza na EAPE ou mesmo na UnB para fazermos nas coordenações. Se há, falta divulgação ou os dias são incompativeis com as coordenações dos professores de matemática, que são às terças-feiras. Na rede particular, não vejo solução. Não há interesse por parte dos gestores. O que importa são os resultados, para isso temos que nos dedicar a uma bateria exaustiva de exercícios" (prof. 6).

"Curso de formação para os professores" (prof. 7).

As respostas sinalizaram uma carência de formação continuada ou cursos de capacitação na sua área em momentos adequados e compatíveis com o horário de trabalho do professor. Lembrando aqui da sua extensa jornada de trabalho, este fator se torna um entrave à busca de solução para esta dificuldade.

Volta-se a lembrar que a última pergunta do questionário era de resposta livre. Assim, os entrevistados explicaram a importância/validade/necessidade da história no ensino de matemática, segundo suas vivências.

Aqui considera-se que as respostas apresentadas foram tão relevantes e tão ricas em suas argumentações, apontando um favorecimento quanto ao uso da história da matemática no ensino, de tal modo que às vezes a história foi considerada indissociável do ensino, que fragmentar as respostas não faria justiça à ideia dos professores, pois, inevitavelmente excluiria aspectos igualmente relevantes. Repete-se, portanto, as respostas na íntegra a seguir:

"Nenhuma forma de conhecimento cientifico está imune de seu contexto histórico e social. Desvinculá-los do ensino da matemática é desmerecer seu caráter não apenas como ciência, mas como uma criação e estudo humano, por mais que 
seja considerada uma ciência exata. Sob esta ótica, o desenvolvimento da história da matemática no ensino é, simplesmente, fundamental" (prof. 1).

"A história da matemática no ensino de matemática pode aumentar o interesse que os alunos têm nas aulas e consequentemente a aprendizagem dos alunos" (prof. 2).

"A história da matemática mostra como surgiram os conceitos e relações matemáticas pela necessidade cotidiana" (prof. 3).

"Resumindo tudo que respondi anteriormente, a história da matemática é muito importante para o entendimento satisfatório de cada conteúdo, visto que sabendo das origens e entendendo a motivação do estudo daquele assunto, o conteúdo se torna mais aplicável no dia-a-dia do estudante. E isso é justamente o que os professores buscam hoje, pois a motivação dos estudantes está cada vez mais menor" (prof. 4).

"A história da matemática pode levar aos alunos o contexto no qual a matemática foi desenvolvida. Assim, os alunos podem ter uma compreensão maior sobre os assuntos e, inclusive, ter maior capacidade de contextualização e também interdisciplinaridade" (prof. 5).

"Se tivesse dominio desse conhecimento, a cada assunto que ministrasse poderia trazer para a sala de aula, mesmo que em pouco tempo. Mas, realmente, para fazer isso, tenho que pesquisar e, atualmente, trabalhando os três turnos, só me restam os finais de semana para corrigir ou elaborar provas" (prof. 6).

"Devemos mostrar para os alunos que o conhecimento sistematicamente produzido pela sociedade se desenvolve a partir de demandas, ou seja, que ninguém inicia ou desenvolve uma teoria sem que haja uma necessidade, uma razão. Daí a importância de se estudar a história da matemática, pois entender o 'como' e o 'por que' faz com que o conteúdo ganhe relevância para a aprendizagem do aluno" (prof. 7).

Constata-se aqui a seriedade do trabalho dos professores, refletida nas formas como eles encaminham as necessidades e propostas de solução para as dificuldades na área e no nível de ensino em que atuam. Neste aspecto, infere-se que o acesso aos conhecimentos mais atuais deveria ser intensificado no nível médio e, neste caso, o trabalho da autora pretende dar uma contribuição adequada a essas necessidades.

Após a análise das informações coletadas na pesquisa exploratória sobre a percepção dos professores quanto ao uso da história da matemática como recurso didático no ensino, infere-se que a maioria professores entrevistados apoiam a tendência de utilizar a história em suas aulas de matemática como instrumento motivador, para 
ajudar os alunos na aprendizagem da matemática. Verifica-se que, embora a internet proporcione uma gama de conhecimentos acerca da história da matemática, foi constatado que alguns professores demostraram sentir falta de materiais adequados disponíveis de consulta. Sabe-se que existem materiais publicados sobre a história da matemática, mas, provavelmente, os professores referem-se a materiais que dão um tratamento concernente ao nível de ensino que o professor pode levar aos alunos. 


\section{Capítulo 5}

\section{CONCLUSÃO}

O conjunto de textos, utilizando a história da matemática referente aos conteúdos de matemática do Ensino Médio, foi elaborado como produto desta dissertação. Sendo assim, considera-se que o objetivo geral do trabalho, construir uma coletânea de textos, sobre a história da matemática direcionados para uso do professor em sua prática pedagógica, a qual contenha um apanhado histórico distribuído cronologicamente e organizado acerca dos conteúdos do Ensino Médio, seguindo as orientações do Currículo em Movimento, foi alcançado.

A pesquisa exploratória foi considerada válida, no sentido de investigar a importância que os professores dão à história da matemática como recurso didático nas suas práticas de aulas. Entendeu-se que os professores poderiam usar a coletânea de textos como referência de apoio didático, ajudando na compreensão, contextualização e significação dos conceitos matemáticos por parte dos alunos. Os resultados da pesquisa sinalizaram que os professores, pelas suas experiências na profissão, consideram importante que os alunos se sintam motivados durante o aprendizado, pois impacta no interesse que os alunos têm pela matemática.

Após a análise dos questionários, foi possível ratificar algumas ideias pensadas no início deste trabalho. Constatou-se que os professores têm real interesse em trabalhar com a história da matemática como mecanismo motivador na sala de aula, desde que tenham condições para isso. Além disso, apenas a utilização dos textos em sala de aula não será uma solução efetiva para o problema da contextualização e motivação dos alunos; entretanto, tem grande potencial de atender a demanda dos professores no sentido de ter acesso a um material com possibilidades concretas de atender às necessidades dos alunos ante a realidade da sala de aula. Desta forma, a utilização dos textos poderá auxiliar de diferentes maneiras a práxis dos professores.

Outro ponto a ser destacado, segundo os professores e a própria autora, é que este trabalho pode contribuir para ampliar a discussão sobre as condições de trabalho em sala de aula no tocante à utilização dos textos. Ocorre que um dos obstáculos dos professores é a extensa grade curricular dos alunos e a cobrança referente à quan- 
tidade de conteúdo curricular a ser aprendida pelos discentes. Em geral, os professores entendem que a qualidade no ensino de alguns pontos da matemática é mais importante de que a quantidade de conteúdo em si. Com isso, as melhores condições de trabalho que possibilitem a utilização do produto desta dissertação também devem ser estudadas e discutidas em novos materiais, levando ao encaminhamento para futuras pesquisas.

Acredita-se que o produto desta dissertação pode ajudar a compor as estratégias para enfrentar o desinteresse dos alunos perante a matemática. Com isso, é pretendido dar o prosseguimento deste trabalho, melhorando e atualizando os textos propostos se necessário, produzindo novos textos que englobem os demais conteúdos que ainda não foram contemplados nesta dissertação. Almeja-se a submissão do produto desta dissertação, como coletânea de histórias em forma de livro paradidático, a uma publicação, subsidiada pela Secretaria do Estado de Educação do Distrito Federal, para ser amplamente distribuído em escolas públicas da rede, a fim de que os professores de matemática possam ter acesso a esse material e usá-los em suas práxis na regência de classe, com vistas a contribuir com o sucesso escolar de seus alunos em matemática. 


\section{Referências Bibliográficas}

[1] ALVES, A. M. M.; LOPES, L. S. A história da matemática em sala de aula: propostas de atividades para a educação básica. In: XX EREMAT - Encontro Regional de Estudantes de matemática da Região Sul, 2014, Bagé-RS. Anais do Encontro Regional de Estudantes de matemática da Região Sul. PelotasRS: Universidade Federal de Pelotas, 2014.

[2] BAYER, A.; BRITTO, S. L. M. O Uso da História no ensino da matemática e a Opinião dos Professores de matemática do Ensino Médio da $2^{\text {a }}$ CRE quanto ao uso desse recurso. Acta Scientiae, Canoas-RS, v. 9, n. 1, p. 41-62, jan./ jun. 2007. BRASIL. Constituição Federal, promulgada em 5 de outubro de 1988. Brasília: Centro Gráfico do Senado Federal, 1988.

[3] _ _ Parâmetros Curriculares Nacionais. Ensino Médio. Brasília: Secretaria do Ensino Médio-Ministério da Educação, 2010.

[4] L Lei $\mathbf{n}^{\mathbf{o}} \mathbf{4 . 0 2 4}$, de 20 de dezembro de 1961. Fixa as diretrizes e bases da educação nacional. Diário Oficial da União, Brasília, 27 dez. 1961. Disponível em: <http://www.planalto.gov.br/ccivil_03/leis/14024.htm>. Acesso em: 03 ago. 2016

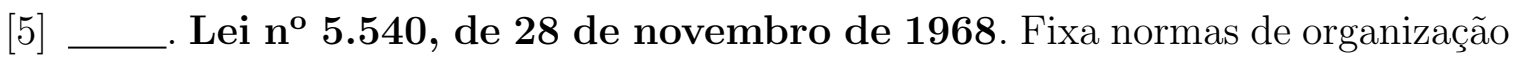
e funcionamento do ensino superior e sua articulação com a escola média, e dá outras providências. Diário Oficial da União, Brasília, 29 nov. 1968, Seção 1, p. 10369. Disponível em: <http://www2.camara.leg.br/legin/fed/lei/1960-1969/lei5540-28-novembro-1968-359201-publicacaooriginal-1-pl.html>. Acesso em: 03 ago 2016.

[6] _. Lei $\mathbf{n}^{\circ}$ 9.394, de 20 de dezembro de 1996. LDB. Estabelece as diretrizes e bases da educação nacional Diário Oficial da União, Brasília, 20 dez. 1996. Disponível em: <http://www.planalto.gov.br/ccivil_03/leis/L9394.htm>. Acesso em: 14 ago. 2016. 
em <http://www.planalto.gov.br/ccivil_03/leis/2002/L10406.htm>. Acesso em 19 jul. 2016.

[8] _. Lei 13.005, de 25 de junho de 2014. Aprova o Plano Nacional de Educação - PNE e dá outras providências. Disponível em http://www.planalto.gov.br/ccivil_03/_ato2011-2014/2014/lei/113005.htm Acesso em: 14 ago. 2016.

[9] _. Secretaria de Educação Básica. Ministério da Educação. Diretrizes Curriculares Nacionais da Educação Básica. Brasília, 2013. Disponível em: <http://portal.mec.gov.br/index.php?option=com_docman\& view $=$ download \&alias $=15547$-diretrizes-curiculares-nacionais-2013-pdf-1\&Itemid $=30192>$. Acesso em: 17 jul. 2016 .

[10] _. Secretaria de Educação Básica. Ministério da Educação. Orientações Curriculares para o Ensino Médio: Linguagens, códigos e suas tecnologias. Brasília, 2006. Disponível em: $<$ http://portal.mec.gov.br/seb/arquivos/pdf/book__ volume_02_internet.pdf $>$ Acesso em: 17 jul. 2016.

[11] BROLEZZI, A. C. ; MOTTA, C. D. B. A influência do positivismo na história da educação matemática no Brasil. In: CONGRESSO LUSO-BRASILEIRO DE HISTÓRIA DA EDUCAÇÃO, 6, 2006, Uberlândia. Anais... Rio de Janeiro: Associação Nacional de Pós- Graduação e Pesquisa em Educação (ANPED), 2006. 1 v. p. $1-12$.

[12] DAMBROS, A. A. O conhecimento do desenvolvimento histórico dos conceitos matemáticos e o ensino de matemática: possíveis relações. 2006. 183 f. Tese (Doutorado em Educação) - Universidade Federal do Paraná, Curitiba, 2006.

[13] D'AMBROSIO, U. A era da consciência: aula inaugural do primeiro curso de pós-graduação em ciências e valores humanos no Brasil. 3 ed. São Paulo: Editora fundação Peirópolis, 1997.

[14] _ Educação matemática: da teoria à prática. 22 ed. Campinas: Papirus, 2011. Coleção Perspectivas em Educação matemática.

[15] DISTRITO FEDERAL. Secretaria de Educação do Distrito Federal. Currículo em Movimento da Educação Básica. Brasília, 2014. Disponível em: $\quad$ <http://www.se.df.gov.br/component/content/article/282-midias/443curriculoemmovimento.html>. Acesso em: 17 jul. 2016. 
[16] EVES, H. Introdução à história da matemática. Tradução Hygino H. Domingues. 5. ed. - Campinas, SP: Editora da Unicamp, 2011.

[17] _ Tópicos de história da matemática para uso em sala de aula. São Paulo: Atual, 1992. (Col.).

[18] IEZZI, G. Fundamentos da matemática Elementar. São Paulo: Atual, 2005. (Col.).

[19] IFRAH, G. História universal dos algarismos: a inteligência dos homens contada pelos números e pelo cálculo. Rio de Janeiro: Nova Fronteira, 1997.

[20] KATZ, V. J. História da matemática. Tradução de Ana Sampaio e Filipe Duarte. Lisboa: Fundação Calouste Gulbenkian, 2010.

[21] LINTZ, R. G. História da matemática, 2. ed. Campinas: Unicamp, 2012. (Volume 2).

[22] MACHADO, N. J. et al. Vivendo a matemática. São Paulo: Scipione, 2000.

[23] MENDES, I. A. O uso da história no ensino da matemática: reflexões teóricas e experiências, Belém - PA: EDUEPA, 2001. 90p.

[24] MENEZES, J. E. Concepções de professores sobre a inserção da história no ensino das ciências: potencialidades e limites. In: Anais do XIV Congresso Internacional de Tecnologia na Educação. Recife: SENAC, 2014. Disponível em: <http://www.pe.senac.br/ascom/congresso/trabalhos.asp>. Acessado em: 14 jun. 2016.

[25] MIGUEL, A. Três estudos sobre história e educação matemática. 1993. 274 f. Tese (Doutorado em Educação) - Universidade Estadual de Campinas, Campinas-SP, 1993.

[26] PROFMAT. Apresentação. Página eletrônica do PROFMAT. Disponível em: $<$ http://www.profmat-sbm.org.br/organizacao/apresentacao>. Acessado em: 13 mar. 2016 


\title{
APÊNDICE
}

\author{
UNIVERSIDADE DE BRASÍLIA - DEPARTAMENTO DE MATEMÁTICA \\ PROGRAMA DE PÓS-GRADUAÇÃO EM MATEMÁTICA PROFISSIONAL \\ HISTÓRIA DA MATEMÁTICA PARA A PRÁTICA DOS PROFESSORES \\ DO ENSINO MÉDIO \\ PESQUISA PARA PROFESSORES DO ENSINO MÉDIO \\ POR ANA GABRIELA DE BRITO DE MOURA \\ ORIENTADA PELA PROF ${ }^{\mathrm{a}}$ DR $^{\mathrm{a}}$ JOSINALVA ESTACIO MENEZES $^{-}$
}

Esta pesquisa faz parte da dissertação de mestrado da proponente e visa investigar a percepção dos professores quanto ao uso da história da matemática como recurso didático no ensino. Sua participação é de extrema importância. Obrigada pela colaboração.

\section{PERFIL}

Tempo de magistério: anos Sexo: ( ) M ( ) F

Trabalha em instituição pública ( ) sim ( ) não

Caso sim, em qual regional de ensino

Sua formação superior foi: ( ) licenciatura em matemática ( ) bacharelado em matemática ( )outra (qual?)

VIVÊNCIA ACADÊMICA:

Enquanto estudante ANTES DO ENSINO SUPERIOR, você teve aulas ou atividades envolvendo a história da matemática?

( ) Sim ( ) Não Caso tenha respondido sim, que atividades?

Na sua graduação ou pós-graduação, você cursou alguma disciplina sobre história da matemática? Caso sim, a disciplina abordou: ( ) Dados bibliográficos de matemáticos. ( ) Abordagem social político cultural da criação das teorias. ( ) Breve cronologia de resultados obtidos no tema ensinado. ( ) Apresentação de uma situação problema antiga e as formas de resolução ao longo da história ( ) Algumas anedotas sobre matemáticos ligados ao conteúdo. ( ) outras (quais?) 
Caso não, você gostaria que tivesse? ( ) Sim ( ) Não. Por que?

Você acredita que a história da matemática inserida nas aulas pode ajudar o aluno na aprendizagem da disciplina matemática? Por quê?

Você utiliza em suas aulas ou atividades a história da matemática? ( ) Sim ( ) Não Caso sim, de que maneira? Caso não, por que?

Caso você considere que os professores enfrentam dificuldades para utilizar a história no ensino de matemática no seu cotidiano profissional, o que faz, a que tipo de material e fonte de consulta deveria ter acesso e o que acha que deveria/poderia ser feito para melhorar a situação?

Por favor, explique qual é para você a importância/validade/necessidade da história no ensino de matemática. Caso queira acrescentar alguma opinião ou comentário, fique a vontade para apresentá-lo aqui. 